\title{
Democracia deliberativa hoje: desafios e perspectivas
}

\author{
Deliberative democracy today: \\ challenges and perspectives
}

A ideia de que uma comunidade política consegue fazer escolhas coletivas melhores e democraticamente mais legítimas se o juízo dos seus cidadãos for depurado por via de uma troca pública, livre, inclusiva e informada de argumentos tem um apelo intuitivo, cujo lastro se estende, no nosso imaginário, até ao berço da democracia, na Grécia Antiga. Com efeito, é em Aristóteles que encontramos o primeiro grande apologista do valor da deliberação em política. No entender do estagirita, é a capacidade para aduzir argumentos, "para tornar claro o útil e o prejudicial e, por conseguinte, o justo e o injusto" (Aristóteles, 1992, \$1253a), que confere aos seres humanos o seu caráter distintamente político. Por conseguinte, é através da deliberação pública com vista à justiça - noutras palavras, é através do envolvimento dos cidadãos na discussão e justificação pública da orientação futura da sua ação enquanto comunidade - que, para Aristóteles, o homem se faz homem, e a comunidade política se faz mais do que mera soma ou agregado de partes.

Apesar dessa longínqua raiz aristotélica, o revivalismo recente do paradigma democrático deliberativo data apenas da década de 1980 (Habermas, 1985, 1996; Elster, 1986; Cohen, 1986, 1989; Manin, 1987), e tem por pano

É pesquisadora no Instituto de Ciências Sociais da Universidade de Lisboa (Lisboa, Portugal), professora convidada no Murray Edwards College, Universidade de Cambridge (Cambridge, Inglaterra), e professora da Universidade de York (York, Inglaterra). E-mail: monica.vieira@ics.ul.pt.

** É pesquisador no Instituto de Ciências Sociais da Universidade de Lisboa (Lisboa, Portugal) e professor na Universidade de Cambridge (Cambridge, Inglaterra). E-mail: fcs23@ics.ul.pt. 
de fundo o crescendo de críticas teóricas à democracia liberal representativa (cuja suposta "crise" marcava, então, como agora, a agenda política), além do insistente apelo à recuperação da dimensão participativa da política (ainda que a relação entre deliberação e ativismo político esteja, ainda hoje, longe de ser pacífica). ${ }^{1}$ Nas décadas seguintes, a ideia de deliberação instituiu-se como o ideal regulador da esmagadora maioria das propostas teóricas sobre a natureza da democracia. Dessa forma, no final da década de 1990, o modelo da democracia deliberativa ocupava já uma posição dominante, havendo quem afirmasse que estávamos perante uma proposta teoricamente amadurecida (Bohman, 1998). Isso deixava o caminho aberto ao passo seguinte na agenda de investigação: a saber, o estudo da relação entre, por um lado, o ideal de democracia deliberativa e suas componentes teóricas, e, por outro, as práticas deliberativas reais e questões mais concretas de design institucional. Só dessa forma se poderia efetuar o teste empírico à adequação, proficuidade e limites do paradigma democrático deliberativo. ${ }^{2}$

Vinte anos transcorridos, importa, pois, fazer o balanço, para tal discutindo, por um lado, algumas das dificuldades, teóricas e práticas, que o ideal de democracia deliberativa continua a enfrentar, ${ }^{3}$ e especificando, por outro, quais as funções que a deliberação deve ainda ser chamada a desempenhar num contexto político democrático. Esses dois objetivos estruturam o nosso argumento neste artigo. Na sua primeira seção, confrontamos o modelo deliberativo com a concepção que dominou a reflexão sobre (e o estudo empírico da) democracia a partir do final da Segunda Guerra Mundial nos Estados Unidos e Europa: a concepção agregativa de democracia de recorte economicista e utilitário.

A seção seguinte debruça-se sobre alguns dos maiores desafios colocados à implantação prática da democracia deliberativa neste princípio do século XXI. Em particular, discutimos críticas comumente ouvidas de que a deliberação reproduz desigualdades socioeconômicas e desigualdades cognitivas de

\footnotetext{
A expressão "democracia deliberativa" surge pela primeira vez em 1980, no título de um artigo de Joseph Bessette, em que os princípios fundadores da Constituição Americana são apresentados como destinados a assegurar uma deliberação pública efetiva, sobretudo dentro do próprio Congresso (Bessette, 1980).

Veja-se, por exemplo, Sunstein (2002); Goodin (2000, 2003); Dryzek (1990, 1996, 2002); Fishkin e Luskin (2000); Luskin, Fishkin e Jowell (2002); Steiner et al. (2004); Gutmann e Thompson (2004); Fung (2004); Ryfe (2005).

Era, pelo menos, o que James Bohman afirmava no seu survey article de 1998 sobre democracia deliberativa, que constitui um ótimo ponto de partida para a presente análise (Bohman, 1998).
} 
base, e de que é irrelevante dada a dificuldade de multiplicação dos encontros face a face numa sociedade de massas.

Ainda nessa seção, discutimos a tentativa de institucionalização da democracia deliberativa por via da criação de minipúblicos, que têm vindo a ganhar adeptos nos últimos anos, prestando particular atenção à questão da sua representatividade. São assim examinadas várias tentativas de justificação dos minipúblicos pela sua alegada ligação representativa ao público em geral. Essas tentativas fundam-se em concepções múltiplas de representação - descritiva, de perspectivas, discursiva ou fundada em critérios de responsividade - que nos propomos escrutinar.

Finalmente, concluímos com uma reflexão sobre os riscos de despolitização que o centrar das expectativas de realização da democracia deliberativa nos minipúblicos acarreta, fazendo um apelo a uma reinscrição do ideal deliberativo no dia a dia dos cidadãos, na forma como chegam à formação das suas opiniões e como co-constroem as suas "preferências" políticas em interação com os seus representantes eleitos.

\section{Deliberação versus agregação}

À "viragem para a linguagem" operada no campo da filosofia nos anos 1970 seguiu-se, cerca de vinte anos mais tarde, uma "viragem para a deliberação" no campo da teoria política. Tanto num como noutro caso, a expressão "viragem" capta uma mudança substantiva e relativamente rápida do enfoque analítico, capaz de atrair um número considerável de autores. Em particular, a viragem para a deliberação faz-se em aberta ruptura com as visões puramente instrumentais da democracia, quer de matriz elitista, quer de matriz economicista, à altura dominantes. ${ }^{4}$ Nelas, a democracia sai caracterizada ora como um mecanismo de garantia de competição pacífica entre elites pelo controle do aparelho do Estado, ora como instrumento de agregação de preferências pré-políticas, expressas isoladamente por uma

\footnotetext{
Aqui cumpre distinguir entre a teoria da escolha racional - o paradigma atualmente dominante em microeconomia e em alguns domínios da ciência política empírica, que identifica racionalidade humana com a capacidade de escolher a melhor opção face a um conjunto fixo de preferências e de constrangimentos - e a teoria da escolha social, igualmente metodologicamente individualista e baseada numa concepção instrumental da racionalidade, mas orientada para problemas de decisão coletiva resultantes da agregação de preferências, valores e interesses individuais (Arrow, 1951). Se a primeira é tipicamente utilizada para explicar decisões individuais, a segunda visa explicar a lógica (e paradoxos) da agregação de tais decisões ou preferências. Para uma análise crítica destas perspectivas, veja-se Baert e Silva (2010, p.125-152).
} 
espécie de "cidadão-consumidor" soberano, cuja atividade política crucial é o voto individual e secreto, aqui entendido não como uma ação pública, mas antes como um ato privado. Logo, se as decisões relativas ao uso do poder de Estado são, nesse modelo, coletivas, são-no apenas na medida em que combinam vontades, preferências ou desejos individuais, que estão envolvidos num processo de competição política. Fica assim arredada das teorias da democracia de inspiração economicista qualquer noção de que o bem comum se possa distinguir do mero somatório ou simples combinação de preferências individuais, tidas por normativamente fundamentais e definidas à parte do próprio processo político. Aliás, os teóricos da escolha social são os primeiros a reconhecer que os mecanismos de agregação não permitem chegar a uma opinião pública sobre $u m$ bem comum, ao que imediatamente acrescentam que, onde haja uma significativa diversidade de interesses ou preferências, esse bem comum, aceitável por todos, simplesmente não existe (Riker, 1982).

Sob o pretexto de uma pretensa neutralidade axiológica, que carrega afinal a marca da ideologia, é uma imagem estritamente privatística e instrumental da democracia que emerge sempre que o fórum é concebido à luz do mercado, e o individualismo metodológico é assumido como premissa para a análise do campo político. Para a teoria da escolha racional, o indivíduo, enquanto ator político racional, é um ator puramente estratégico, uma espécie de sucedâneo do homo economicus, visando otimizar as suas escolhas face aos interesses que tem e às alternativas que lhe são colocadas. E o processo democrático fica praticamente esgotado nos mecanismos eleitorais de agregação de interesses ou preferências que o precedem. Contra essa imagem reducionista do campo político democrático e do tipo de racionalidade que o enforma, os teóricos da democracia deliberativa desenvolveram uma concepção comunicativa da racionalidade e ação humanas, orientada já não para o ganho, mas antes para o entendimento, e vieram relembrar que a tarefa da política não é apenas, como acontece com o mercado, eliminar ineficiências, mas também, e sobretudo, criar justiça. Nesta os teóricos da democracia deliberativa encontram um "bem social" singularmente importante, que apenas a deliberação política racional, aberta a todos os potencialmente afetados, pode ter esperança de produzir e, mais do que isso, de publicamente justificar. Sem os "recursos morais" (Offe e Preuss, 1991) que lhe oferece a deliberação, entendem os "deliberacionistas", a democracia ver-se-ia incapacitada quer de 
gerar, quer de sustentar a prazo soluções coletivas legítimas para problemas politicamente controversos.

Dessa forma, a democracia deliberativa constitui, antes de tudo mais, um ideal de legitimidade política. Convém aqui socorrermo-nos das palavras de John Dewey, um dos pais fundadores do paradigma deliberativo, para fazermos luz sobre essa questão da legitimação. Segundo Dewey, a regra da maioria, votada a si mesma, é tão cega e absurda quanto os críticos da democracia fazem crer. Mas a legitimidade da política democrática reside precisamente no fato de ela não ser redutível às escolhas majoritárias. Antes pelo contrário, numa democracia, "a contagem de cabeças exige o recurso anterior a métodos de discussão, consulta e persuasão" (Dewey, 1927, p. 207-208, tradução dos autores), sendo no aperfeiçoamento das condições e procedimentos sob os quais se desenvolve o debate político que reside o problema essencial do domínio público e a possibilidade de redenção do projeto democrático. ${ }^{5} \mathrm{Tal}$ como Dewey, também os defensores mais recentes do paradigma democrático deliberativo insistem que as decisões políticas são legítimas apenas na medida em que sejam tomadas no âmbito de um processo deliberativo alargado que implique a troca pública de argumentos sobre as propostas em consideração. Argumentos que são oferecidos por e $a$ um núcleo alargado de participantes livres e iguais (designadamente, todos aqueles potencialmente afetados pela decisão a tomar, ou os seus representantes), guiados por valores como a racionalidade, a imparcialidade, a reciprocidade e o respeito mútuo, porque apenas assim se pode justificar o exercício do poder político coletivo em democracia. Nesse ideal de argumentação pública encontram os "deliberacionistas" um ideal regulador, uma normatividade que interpela o mundo real, e que aspira a servir de critério de construção de fóruns institucionais deliberativos, assim como de critério de aferição da legitimidade das decisões políticas neles efetivamente tomadas. Essa legitimidade pressupõe a existência de canais de comunicação entre esses fóruns e uma esfera pública informal mais alargada, estruturada sobre condições socioeconômicas favoráveis à participação, associação e expressão, sem as quais seria impossível garantir que as instituições representativas se mostrassem receptivas a ouvir o fórum, a responder às suas interpelações e a apresentar razões que justifiquem as leis e políticas públicas sob as quais vivemos.

Para uma discussão das origens da democracia deliberativa no pragmatismo filosófico de Dewey, William James e G.H. Mead, veja-se Silva (2004). 
Característica central do modelo da democracia deliberativa é, pois, o enfoque no processo dialógico enquanto processo de real interação argumentativa por intermédio do qual os participantes oferecem mutuamente razões, em defesa de determinada opinião, posição ou proposta, ou em objeção a opiniões, posições ou propostas avançadas por outrem. A expectativa é que os conflitos em matéria de questões de interesse comum possam ser resolvidos racionalmente, mediante o reconhecimento da força do melhor argumento, o que pressupõe que as partes adotem uma predisposição para alterar a sua opinião e redefinir as suas preferências e interesses, se persuadidas por razões que entrem em conflito com, e finalmente destronem, as suas opiniões, preferências e interesses de partida. Nisso a deliberação distingue-se da negociação. Se, nesta última, o acordo pode ser extraído por recurso a estratégias de engodo, mentira, promessa ou ameaça, e as partes obedecem primariamente ao seu interesse próprio, já na deliberação o consenso (idealmente) obtido deve ser racional, e portanto alcançado por via da persuasão, não da coerção, encontrando-se as partes imparcialmente localizadas, e orientadas ao bem comum. ${ }^{6}$ Quando assim acontece, isto é, quando cada um se esforça por encontrar razões que sejam plausíveis para os outros, reconhecendo esses outros como iguais, a expectativa é que o resultado da escolha coletiva, mesmo que não consensual, e determinado em última análise pelo voto majoritário, goze de uma legitimidade acrescida. Esta advém-lhe de ser produto de um processo livre de formação da opinião e da vontade, em que toda a justificação oferecida assenta em considerações que os outros, cuja conduta será governada por essas mesmas decisões, possam aceitar, ou, pelo menos, não possam razoavelmente enjeitar. Tal exigência de fundar as nossas escolhas coletivas em razões que não sejam apenas "as nossas razões", mas antes interpelem "o outro", em cujo papel fazemos o esforço de nos colocar, encontra-se ausente das concepções agregativas da democracia. Em claro contraste, para os defensores da democracia deliberativa, este ato de oferecer aos outros razões efetivamente públicas em suporte das normas e das opções políticas que regem a nossa vida em comum é o ato político por excelência, e o elemento fundacional da nossa autonomia política, individual e coletiva.

Diz-se que A exerce coerção sobre B quando, pelo uso da força ou a ameaça da sanção, as preferências ou interesses de A levam B a fazer (ou, pelo menos, mudam a probabilidade de B fazer) aquilo que não faria de outra forma. 
Apesar das expectativas de que o processo deliberativo produza interesses cada vez mais generalizáveis, e com maiores áreas de sobreposição entre si, é igualmente de reconhecer que a deliberação não responde satisfatoriamente à necessidade de tomada de decisão sobre questões complexas em sociedades crescentemente plurais como as nossas. Mesmo os defensores mais acérrimos do modelo deliberativo concordam que este não visa, e nem sequer reúne as condições necessárias para, substituir a agregação de preferências individuais. A deliberação pode ajudar a transformar preferências, ao encorajar os participantes a assumirem uma perspectiva menos egoísta sobre questões de interesse comum, mas essas preferências têm ainda de ser agregadas de alguma forma, que não é em si mesma deliberativa, se quisermos auscultar a vontade popular, de modo a legitimar o processo de decisão política. A questão não é, pois, se a deliberação pode substituir a agregação, mas antes se, e em que termos, a pode melhorar.

Uma das principais motivações por detrás da recente recuperação do modelo democrático deliberativo prende-se justamente com a esperança depositada nesse modelo em dar resposta a problemas crônicos enfrentados pela agregação. Um desses problemas refere-se à instabilidade intrínseca à regra da maioria. Como William Riker demonstrou, uma maioria pode ter origem em qualquer um dos elementos do conjunto de alternativas em questão pelo que não são as preferências individuais a determinar a decisão da maioria, mas os constrangimentos institucionais em vigor. Todavia, será que tal impossibilidade de determinar quais as preferências relevantes para a realização de escolhas coletivas se aplica de igual forma à deliberação? Julgamos que não. A razão pela qual a deliberação se apresenta como uma alternativa superior à agregação neste domínio prende-se com a posição ocupada pelos constrangimentos institucionais em cada uma delas. Se na agregação é assumido que estes últimos são exógenos ao "mundo de gostos e valores" (Riker, 1982, p. 190), com as consequências acima descritas, no caso da deliberação os requisitos procedimentais necessários à operacionalização do ideal de deliberação livre, entre iguais, não representam constrangimentos institucionais externos, ou arbitrários, mas são antes premissa de autogoverno, numa sociedade democrática, entendida como um sistema de cooperação entre cidadãos livres e iguais. Isso porque as preferências, interesses e valores relevantes são aquelas que sobrevivem ao filtro procedimental da deliberação democrática, não aquelas que lhes são 
anteriores (Cohen, 1997, p. 82). Ao associar a legitimidade democrática das decisões políticas à observância desses procedimentos, e à natureza das razões avançadas (isto é, mutuamente aceitáveis e globalmente acessíveis), a democracia deliberativa oferece-nos, assim, um critério de legitimidade potencialmente mais inequívoco do que o voto.

Para além dessa instabilidade intrínseca à regra da maioria, a agregação defronta-se ainda com um segundo problema de instabilidade. Neste caso, o problema remete para a vulnerabilidade dos mecanismos agregativos, como é o caso do voto, à manipulação. Quaisquer que sejam os métodos de escrutínio eleitoral, existem sempre duas formas possíveis de manipulação dos resultados. Por um lado, aqueles que definem e controlam os procedimentos podem manipular a agenda, seja por meio da exclusão de temas ou da alteração da ordem de trabalhos. Por outro lado, mesmo aqueles que não controlam a agenda podem fazer uso do chamado "voto estratégico" para manipular os resultados por meio da revelação falsa de preferências (Riker, 1982, p. 137). Outra forma de manipulação é a prática conhecida por "gerrymandering", isto é, o redesenhar dos círculos eleitorais de modo a favorecer um determinado grupo ou partido. Em nosso entender, a deliberação pode, se não resolver, pelo menos minorar esse problema. Referimo-nos ao seu papel na justificação racional das soluções institucionais que visam impedir tais manipulações. É evidente, porém, que tal justificação racional está longe, por si só, de garantir a estabilidade dos instrumentos de agregação das preferências, uma vez que não podemos confundir transformação de preferências com sua convergência e homogeneização. Ao justificar racionalmente determinado mecanismo agregativo, a deliberação ajuda a clarificar o que está em causa (por exemplo, na eleição dos nossos representantes políticos), embora o desacordo sobre as dimensões desse problema (por exemplo, como devem ser configurados os círculos eleitorais) possa manter-se, independentemente do caráter mais ou menos reflexivo da discussão. A vulnerabilidade desses mecanismos à manipulação e à instabilidade, por conseguinte, no geral, mantém-se (Knight e Johnson, 1994, p. 283).

Mas se a deliberação não deve ser vista como uma panaceia para todos os problemas de instabilidade que afetam a agregação, há boas razões para pensar que ela a pode complementar eficazmente. Tanto assim que o processo (deliberativo) de formação da opinião pode não respeitar todos os pressupostos procedimentais da situação deliberativa, e ainda assim 
ter importantes consequências positivas para a qualidade da democracia. Atentemos, por exemplo, para o caso do envolvimento do Reino Unido na invasão do Iraque por forças norte-americanas em março de 2003. Nos meses que antecederam a invasão militar, Tony Blair deu uma série de justificações para o apoio britânico à iniciativa da administração Bush, desde a histórica relação de amizade entre os dois países, até argumentos relacionados com o perigo imediato que Saddam Hussein representava para o próprio povo iraquiano e países vizinhos e com a ameaça colocada pela possível associação de Estados fora da lei (como o Iraque) com grupos terroristas (como a Al-Qaeda), sobretudo à luz da sua eventual posse, ou capacidade para desenvolver, armas de destruição em massa. À altura, a qualidade da deliberação não foi a ideal, tendo ficado marcada por sucessivos episódios de alegado engodo (por exemplo, na constituição do "dossiê" quanto às provas da existência de armas não convencionais no Iraque) e negociação estratégica (por exemplo, sugerindo que os interesses do Ocidente ficariam melhor servidos por um Iraque democrático). Ademais, essa troca de argumentos não impediu a participação das tropas inglesas no conflito com a chancela parlamentar (igualmente ineficaz nesse sentido foi a mobilização popular de centenas de milhares de manifestantes em Londres, cujo slogan, "Not in my name", ficou célebre) ${ }^{7}$.

O que essa deliberação permitiu foi que, após a intervenção militar no Iraque, houvesse lugar a um debate mais informado do que teria acontecido caso tal deliberação não tivesse ocorrido. Uma componente importante desse debate é a comissão de inquérito, criada em 2009, sobre a guerra do Iraque ("Iraq inquiry"), presidida por Sir John Chilcot e constituída por cinco reconhecidas personalidades, incluindo o historiador britânico Martin Gilbert. ${ }^{8}$ Em discussão, encontram-se justamente as razões oferecidas por Tony Blair para justificar o envolvimento britânico nesse conflito. A primeira das várias audições públicas ao ex-primeiro-ministro britânico teve lugar em janeiro

Vide http://news.bbc.co.uk/2/hi/uk_news/2765041.stm.

8 Essa foi a quinta comissão de inquérito sobre a Guerra no Iraque e prometia ser a mais completa e profunda. Das restantes comissões de inquérito salientam-se a chamada comissão Hutton, de 2004, que se debruçou sobre as circunstâncias da morte de David Kelly - o cientista do ministério da Defesa que se suicidou após o seu nome ter sido divulgado como a fonte da BBC que acusava o gabinete de Tony Blair de ter empolado informações vindas dos serviços secretos - e a comissão Butler, de julho desse mesmo ano, que se dedicou ao mesmo problema da manipulação da informação disponibilizada pelos serviços secretos. 
de 2011, tendo sido acompanhada em direto por milhões de telespectadores. Sejam quais forem as conclusões dos trabalhos da comissão Chilcot (cujo relatório foi publicado em 2012) ${ }^{9}$, uma coisa parece certa: sem deliberação, ainda que imperfeita, saberíamos hoje muito menos sobre as circunstâncias e motivos que levaram o Reino Unido a juntar-se ao esforço de guerra norte-americano, encontrando-se o subsequente processo de escrutínio público, e de responsabilização política, nessas circunstâncias, coartado. Desse ponto de vista, a agregação tem na deliberação uma forte aliada para ajudar a des/ legitimar decisões políticas conforme os argumentos em confronto tenham sido considerados na base dos seus reais méritos, ou antes na base de assimetrias no acesso à informação e na capacidade negocial das partes ou diferentes interesses políticos em competição.

Essa tomada de decisão na base do mérito dos argumentos apresentados é especialmente importante quando estejam em causa questões fraturantes, porque põem em jogo mundivisões e valores morais potencialmente incompatíveis, em que é de esperar a persistência de um desacordo razoável, mesmo após o momento deliberativo. A esse núcleo de questões pertence, por exemplo, a questão do aborto, que muitos encaram como contrapondo dois valores incompatíveis, a vida do feto e a liberdade da mulher, ou a questão do casamento homossexual, em que vozes a favor do casamento enquanto estatuto legal exclusivo à família nuclear se contrapõem a vozes a favor do mesmo instituto enquanto direito civil dos homossexuais.

A deliberação não tem expectativas de resolver conflitos morais profundos como esses. Mais ainda, ao exigir que as partes articulem a razão das suas preferências, pode mesmo, sobretudo onde as razões oferecidas sejam mutuamente inacessíveis (porque, por exemplo, de índole religiosa), agravar o entrincheiramento de cada parte na sua posição inicial. E mesmo onde as razões oferecidas pelas partes sejam mutuamente acessíveis, os argumentos trocados perfeitamente razoáveis, e haja acordo relativamente a certos fatos, a resposta a esses fatos - isto é, a forma como eles são pesados e avaliados pode continuar a ser conflitante (por exemplo, quanto a saber se aquilo que as partes concordem ser um feto é, ou não, pessoa). Daí que, não raramente, em questões moralmente controversas, a deliberação deságue na submissão

As audições públicas de figuras relevantes ao processo começaram em novembro de 2009 e terminaram em fevereiro de 2011. O relatório final foi entregue ao governo britânico no verão de 2012. Vide http://www.iraqinquiry.org.uk/. 
da questão a referendo, ou ao parlamento, onde a maioria dos representantes toma a decisão pela restante população, fazendo-o, frequentemente, na base, não da disciplina partidária, mas da escolha moral individual. Todavia, é ainda, e apenas, a deliberação que pode colocar grupos em contenda perante visões alternativas de uma mesma questão, e seus eventuais de/méritos, assim contribuindo para legitimar a decisão majoritária final, sobretudo perante os grupos perdedores, bem como para mitigar efeitos de polarização, produzidos por uma deliberação apenas interna a grupos de "indivíduos que comungam da mesma opinião (like-minded individuals)". ${ }^{10} \mathrm{E}$, apesar de, onde haja incompatibilidade de valores de fundo, os desacordos razoáveis se tenderem a manter, por via da deliberação esses desacordos poderão ser separados de aspectos da mesma questão susceptíveis de alguma acomodação (por exemplo, defensores e opositores da despenalização do aborto, podem chegar a acordo sobre a desejabilidade de políticas de prevenção, como a educação sexual nas escolas). Mas, para que esses efeitos benéficos da deliberação estejam de fato disponíveis, e ela possa criar, mesmo na dissensão, terreno comum, é necessário que as partes tenham igual oportunidade de acesso aos canais de influência política, que respeitem e tomem a sério as visões dos seus oponentes, e que estejam abertas à possibilidade de revisão das suas próprias posições. Estas são condições de difícil preenchimento. Todavia, e tal como vimos, mesmo em condições sub-ótimas, a existência de um sistema deliberativo, composto de vários fóruns deliberativos comunicantes, em que predomina a troca de razões, submetidas ao filtro da publicidade, favorece a legitimidade da decisão finalmente alcançada.

O fato de que, como acabamos de ver, a deliberação se relaciona de múltiplas formas com a agregação não significa que aquela se reduza a um complemento, mais ou menos eficaz, desta. A deliberação tem um valor intrínseco. Esse valor reside no conjunto de competências políticas e virtudes cívicas por ela promovidas, entre as quais se destacam: a educação política que resulta do envolvimento em procedimentos democráticos de avaliação de propostas alternativas; o respeito mútuo que o confronto público de opiniões pode ajudar a promover; as expectativas mais razoáveis acerca do

10 É que, embora a deliberação intragrupo seja, por vezes, benéfica, para produzir posições merecendo circulação pública alargada, que, de outra forma, não emergiriam (note-se que os grupos desfavorecidos tendem a não fazer ouvir a sua voz, ou a vê-la silenciada, em fóruns deliberativos alargados), ela resulta também, com frequência, numa mera amplificação acrítica de predisposições. 
que está ao alcance do decisor político e dos constrangimentos que a ação política enfrenta; e um sentimento de igualdade recíproca que é alimentado pela experiência de ouvir e de se fazer ouvir pelos concidadãos, o que, por seu turno, alimenta a autonomia individual e as capacidades de ação a ela associadas. Essas virtudes não devem ser confundidas com virtudes éticas, como a honestidade ou a sinceridade. As virtudes que a deliberação ajuda a promover revestem-se de um caráter estritamente cívico, tendo diferentes catálogos desse tipo de virtudes sido identificados ao longo da história do pensamento político, sobretudo no âmbito da tradição cívico-republicana. ${ }^{11}$

\section{Democracia deliberativa: reprodutora das desigualdades socioeconômicas?}

Uma das críticas mais recorrentes ao ideal de deliberação pública é a de que a sua tradução prática encontra tamanhos obstáculos que o ideal corre o risco de se transformar em instrumento reprodutor do status quo, perdendo assim todo o seu potencial crítico e emancipatório relativamente às estruturas de poder dominantes. $\mathrm{O}$ modelo deliberativo pressupõe uma igualdade, mutuamente reconhecida, entre participantes. Essa igualdade deve aqui ser entendida não apenas como uma igual oportunidade de acesso aos fóruns deliberativos mas também como uma igual capacidade de neles participar. Na realidade, porém, os pré-requisitos materiais da deliberação estão assimetricamente distribuídos, com clara desvantagem para aquelas camadas da população que já se veem sub-representadas dentro do processo político formal - designadamente, as mulheres, as minorias e os grupos socioeconomicamente mais desfavorecidos, cujos interesses, opiniões e perspectivas se podem ver, de igual forma, excluídos da deliberação na esfera pública informal.

Essas desigualdades de base, que o processo deliberativo, se votado a si mesmo, pode mesmo vir a acentuar, ${ }^{12}$ leva alguns proponentes da deliberação

\footnotetext{
Vide, por exemplo, Pettit $(1997,2001,2003)$ e Silva (2004).

2 Um bom exemplo desse problema é-nos dado pela Assembleia de Cidadãos (AC) para a Reforma Eleitoral de British Columbia, Canadá (2004). Dos 26.500 cidadãos inicialmente selecionados por meio de um método de amostragem aleatória, apenas 1.441 demonstraram interesse em participar nos trabalhos da Assembleia. Desses, somente efetivamente apareceram 964, dos quais foram então sorteados 158 (um homem e uma mulher por cada um dos 79 círculos eleitorais da província) - os quais, sem surpresa, eram desproporcionalmente mais ativistas do que a generalidade da população (Warren e Pearse, 2008, p. 10-11). Mas o problema desse tipo de assembleias deliberativas não se reduz a dar mais voz aos que já têm voz (ex. Dalton, Cain e Scarrow, 2003), isto é, aos já mobilizados. Elas tendem,
} 
a advogarem medidas especiais de estímulo à inclusão de grupos normalmente excluídos em fóruns deliberativos, via práticas de "outreach", bem assim como uma intervenção profunda no sistema educativo, nas políticas sociais redistributivas, e no próprio sistema econômico, com o objetivo de assegurar a todos os cidadãos condições de deliberação mais paritárias - tempo, dinheiro, informação, educação, capacidade argumentativa, entre outras. Procura-se, dessa forma, evitar situações como a ocorrida no processo deliberativo consultivo promovido pelo estado americano de Oregon com vista à reestruturação do seu programa de cuidados de saúde, dirigido às classes de rendimento inferior. Nesse debate público, os membros dessas classes desfavorecidas pouco se fizeram ouvir, e a maioria dos participantes acabou por ser de raça branca e classe média e por não padecer de nenhuma enfermidade. E por uma simples razão: os diretamente afetados pelo programa estavam demasiado ocupados com a sobrevivência para se poderem deixar envolver ativamente na deliberação (Gutmann e Thompson, 2004, p. 17-20).

\section{Democracia deliberativa: reprodutora das desigualdades cognitivas?}

Mas às assimetrias socioeconômicas de base, que determinam diferentes custos no aproveitamento das oportunidades de deliberação, soma-se outro fator de exclusão, desta feita, intrínseco às práticas deliberativas. Referimo-nos às normas informais que estabelecem o que conta como uma "boa razão" ou um "argumento aceitável” num processo deliberativo público. É que, à luz do processo deliberativo ideal, a autoridade "epistemológica" dos argumentos que devem entrar a debate, e ser considerados pelas partes, rege-se por critérios de racionalidade, razoabilidade, imparcialidade e universalidade, mais facilmente atendíveis por uns do que outros. Na deliberação pública, não basta expressar-se, ouvir e fazer-se ouvir. É também necessário falar de uma certa forma. Concretamente, fazer a defesa das suas posições por via de

\footnotetext{
igualmente, a privilegiar os cidadãos cognitivamente mais capazes. Com efeito, outra desigualdade socioeconômica que se viu ampliada na AC foi a desigualdade da escolaridade: $56.4 \%$ dos membros da CA tinham frequentado uma universidade contra apenas $23.9 \%$ da população (James, 2008, p. 113). Por outro lado, o método de seleção quase aleatória pode levar a escamotear desigualdades estruturais. Foi o caso da exclusão de minorias que, não sendo demograficamente representáveis numa amostra nacional, são porém politicamente relevantes no Canadá. Veja-se o exemplo dos aborígenes e outras minorias étnicas: $88.1 \%$ dos membros da AC eram brancos contra apenas $75.1 \%$ da população da província de British Columbia; por outro lado, $11.9 \%$ dos membros da CA eram de minorias étnicas, contra 24.9\% da população provincial (James, 2008, p. 111).
} 
argumentos que os demais não possam razoavelmente enjeitar, porque são trabalhados em termos de uma "literacia comum", e apontam para alternativas de ação coletiva apresentadas como satisfatórias para todos.

Acontece, porém, que, por vezes, essa "literacia comum" esconde atrás de si nada mais, nada menos do que o discurso dominante, e cidadãos com um nível superior de educação formal e maior experiência deliberativa terão, em princípio, maior facilidade em manipulá-lo para formarem argumentos persuasivos, segundo critérios de "autoridade epistemológica" definidos pelo próprio ideal deliberativo. Isso não quer dizer que, noutras circunstâncias menos hegemônicas e reprodutoras de formas de exclusão -, os argumentos dos demais grupos de cidadãos não fossem susceptíveis de generalização convincente. Ou que não haja perspectivas particulares dignas de reconhecimento público na sua particularidade, que discursos como o testemunho ou a narrativa podem mais cabalmente articular - perspectivas essas que não devem ser deixadas de fora da deliberação, sob pena de se negar a reciprocidade democrática que lhe serve de condição. Pois se a reciprocidade depende do esforço de pensar a questão em debate da perspectiva do outro concreto, e não apenas de um outro generalizado, há que reconhecer as dificuldades inerentes a esse exercício.

A reversibilidade de posições, sobretudo quando estas são altamente assimétricas, e se inscrevem em relações de privilégio e opressão (Young, 1997), pode conhecer limites iniludíveis, que nenhum exercício da imaginação conseguirá cabalmente superar (Goodin, 2000). Assim, a capacidade de entendermos o outro concreto depende ultimamente da capacitação para a expressão da sua $v o z$, na primeira pessoa. Sem envolvimento e mesmo sem confronto efetivo com esse outro, naquela voz em que ele escolha exprimir-se, podemos incorrer no risco de construí-lo (e, antes disso, de obrigá-lo a falar) como uma simples projeção de nós mesmos. Daí a relevância de uma deliberação permeável à legitimidade do conflito e a diferentes formas discursivas, que saiba trazer ao processo deliberativo a experiência, os juízos situados, os interesses específicos, e as vozes disruptivas de camadas da população à partida mais desfavorecidas, menos versadas na formalização de argumentos, e menos confiantes na eficácia da sua participação política (Miguel, 2011). É que, muito embora o processo deliberativo se oriente à identificação e construção de esferas de "comunalidade", em que todos nos possamos encontrar, ele não pode, para tal, fechar-se à verdadeira alteridade 
do outro, nem tão pouco à possibilidade, numa democracia sempre presente, de conflito político. Admitir à deliberação apenas o identificavelmente semelhante, e dela excluir tudo o que não se presta a tal identificação, é reduzir a interação democrática a um movimento de revolução em torno de si mesmo.

Por tudo isto é importante um corretivo ao entendimento de que a deliberação, para ser racional, tem de ser isenta de qualquer parcialidade deliberativa, impermeável à emoção e fechada à influência da retórica. É que a seriedade da deliberação política não exclui, antes exige, a coparticipação das duas faculdades, razão e emoção, e dos dois tipos de interação discursiva, a troca racional de argumentos stricto sensu e a persuasão retórica. ${ }^{13}$ Isso é, desde logo, assim, porque tanto uma linguagem "emocional" quanto uma linguagem "racional" se prestam a usos quer comunicativos, quer estratégicos. Dessa forma, o apelo a um discurso "neutral", "objetivo" ou "desapaixonado" pode ser ele mesmo uma manobra retórica destinada a fechar a deliberação a determinados grupos ou a uma discussão verdadeiramente política - e não meramente técnica - do problema coletivo em questão. A isso acresce que a retórica, normalmente identificada com os usos puramente plebiscitários do discurso, pode servir propósitos deliberativos, pela criação de uma relação dinâmica de interlocução entre orador e ouvintes, que chama quem ouve ao uso da sua razão prática, pondo as pessoas a pensar, dando-lhes informação, apresentando-lhes diferentes ângulos de uma e a mesma questão, tornando-as mais reflexivas relativamente às suas opiniões de partida, obrigando-as a ver a sua condição, e a condição coletiva, presente e futura, de uma nova forma.

É de resto duvidoso que a reflexão sobre a coisa pública possa conseguir envolver amplamente as pessoas sem mediação retórica - isto é, sem a combinação de elementos cognitivos e afetivos, impessoais e pessoais, que é típica do discurso persuasivo, um discurso em que o que se diz está indissoluvelmente ligado ao como se diz e ao quem o diz. A busca do bem comum, ou a definição dos termos de um projeto de vida coletivo, não pressupõe, nem se presta, ao tipo de raciocínio neutral, imparcial e impessoal, típico de instituições de natureza científica e/ou judicial, orientadas à explicação de um fenômeno ou à determinação da verdade de um caso, a partir de um ponto de observação distanciado (Yack, 2006). Antes ela obriga o orador a atentar na e a falar $a ̀$ diversidade de preocupações e interesses numa dada

3 Vide, por exemplo: Young (2000), Richardson (2002), Garsten (2006), Yack (2006) e Chambers (2009). 
sociedade, e à possibilidade de conflito entre eles - um conflito que se pode estender ao que deva contar como um argumento deliberativo e à perspectiva a partir da qual as questões públicas devam ser decididas.

Até pelo caráter agonístico da luta política democrática, e pelas diversas concepções da melhor sociedade que a informam, um discurso mais emocional, mais evocativo e mais figurativo - que trabalhe a partir das opiniões dos cidadãos tal como elas existem, para possivelmente as trazer a um momento disruptivo -, pode contribuir mais eficazmente para a abertura de canais de diálogo e de entendimento mútuo entre participantes do que um discurso que troca a persuasão pela justificação a partir de uma perspectiva única, e unicamente revestida de autoridade. Com efeito, privada da sua dimensão afetiva, a troca de perspectivas em que assenta o processo deliberativo pode ver-se destituída da sua força motivacional. A tese de que os modos de consciência afetivos se intrometem negativamente nos trabalhos da razão e, dessa forma, são obstáculo ao distanciamento face às próprias opiniões necessárias ao juízo moral sensato, à adjudicação equitativa e à deliberação justa, enfrenta hoje o desafio duplo, das "novas" ciências do cérebro (Damásio, 1995) e da "vetusta" filosofia moral, de linhagem aristotélica e humeana. Ambas nos alertam para a incapacidade de acionarmos a razão prática - e portanto de deliberarmos com vista à escolha de cursos de ação individual e coletiva - quando esse processo não esteja ancorado em sentimentos ou estados afetivos, começando pela inquietude que estimula a reflexão ao interromper hábitos instalados de resposta, passando pela empatia necessária ao pensar a questão da perspectiva do outro, e terminando na focalização emocional num certo objetivo, que corporizando uma certa concepção do bem coletivo, exerce uma força motivacional e unificadora do nosso pensamento. Dessas ligações emocionais depende não apenas a vontade final de agir num determinado sentido mas também - e decisivamente - a própria justificação dessa ação e das normas que a devem guiar (Krause, 2008).

\section{Democracia deliberativa: irrelevante hoje em dia?}

Outra crítica recorrente ao ideal de democracia deliberativa é que ela é irrelevante nas condições políticas modernas. Esta objeção alicerça-se no pressuposto de que a democracia direta é a forma natural, senão mesmo necessária, de institucionalização do ideal deliberativo. No entanto, nas nossas sociedades, esse regresso a formas diretas de democracia é não ape- 
nas impossível como também indesejável, e isso à luz do próprio princípio deliberativo. Impossível, dado o tamanho da unidade política nacional e o elevadíssimo número de potenciais participantes no processo deliberativo, com os problemas de coordenação que isso levanta - isso para já não falar no valor irrenunciável da liberdade dos "modernos", de não despender a maior parte do seu tempo a deliberar sobre questões políticas, valor que seria aniquilado pela introdução da deliberação como imposição, mesmo que por um dia. Indesejável, porque não é, de todo, garantido, que uma assembleia democrática em massa, com uma agenda perfeitamente aberta, subordinasse as questões políticas mais relevantes (se tais questões ficassem, algumas vez, definidas) a um tratamento deliberativo, em vez de meramente plebiscitário, isso mesmo que, admita-se por mera cogitação, essa assembleia fosse uma possibilidade institucional. Disso se esquecem, amiúde, aqueles que visam substituir o elemento representativo das nossas democracias pela participação direta dos cidadãos no seu próprio governo, designadamente pela via digital, reduzindo os representantes eleitos a meros delegados, cuja ação é o reflexo automático do resultado de sucessivos referendos. No entanto, essa participação digital assume, muito frequentemente, a forma de uma expressão imediata da vontade, formada (e não questionada) em grupos de pares, sem levar em consideração o seu impacto sobre os demais. Veja-se, a esse título, o resultado embaraçoso dos esforços de "crowdsourcing" ${ }^{14}$ envidados pela administração Obama no período de transição entre administrações. Numa altura em que a América estava envolvida em duas guerras, e enfrentava uma das maiores crises econômico-financeiras da sua história, a proposta que obteve maior pontuação on-line foi, pasme-se, a da legalização da marijuana. Ficavam assim claros os perigos de uma democracia em que somos consultados sobre tudo, a todo o tempo, e em que o consentimento é dado, e retirado, não de quatro em quatro anos, mas minuto a minuto. Uma democracia em tempo real, na qual apenas alguns, geralmente os com preferências mais intensas, e os mais "sonoros", têm lugar assegurado, deixando os mais moderados sistematicamente não representados nessa pretensa vox populi, que dá voz aos que já têm voz e silencia todos os demais.

Como David Plotke bem assinala, o contrário da representação não é a participação, mas a exclusão (Plotke, 1997). É que a representação, ao abrir

14 "Crowdsourcing" refere-se à solicitação aos cidadãos de ideias para políticas públicas, permitindo-Ihes votar nas propostas apresentadas. 
um intervalo de tempo entre a deliberação e a decisão, desempenha um papel crítico na estruturação do espaço necessário ao exercício do juízo crítico e à participação política efetiva dos cidadãos, que idealmente assumirá diversas formas, desde a mobilização partidária à ação pública de protesto, e destas a práticas deliberativas que interajam proativamente com as opiniões e visões políticas existentes e estimulem uma maior reflexividade em relação a elas ao exporem-nas a outras opiniões e visões. Isso será possível, claro está, apenas na medida em que os nossos representantes não deliberem apenas entre si, fechados num bolha hermética de influências de corredor, mas antes ouçam e comuniquem com os seus eleitores sobre as opções políticas que enfrentam e a sua relação com a sociedade que visam construir. Eleitores que devem, de resto, ter mecanismos para saber o que faz quem os representa, para assim melhor os poderem responsabilizar, pelo voto, certamente, mas também pela exigência de que lhes sejam apresentadas razões para as prioridades da agenda política, assim como para as leis e as políticas públicas propostas, aprovadas e implementadas pelos diferentes partidos e pelo próprio executivo, apoiado na maioria parlamentar. É que o escrutínio dos cidadãos e seus representantes tem de estender-se ao ciclo completo da ação pública, que não para no momento da decisão, mas antes se estende pela fase igualmente, se não mais, importante da implementação.

Mas se, como vimos, a institucionalização do ideal deliberativo não tem de passar pela democracia direta, num passado recente ela tem tido por face mais visível a criação de fóruns deliberativos visando combinar as vantagens da representação com as vantagens da democracia participativa. Esses fóruns têm variado substantivamente na sua forma concreta de institucionalização. A participação pode ser voluntária ou involuntária; os fóruns podem incluir, para além dos cidadãos, peritos e oficiais governamentais, ou excluí-los; os poderes desses fóruns podem ser consultivos ou estender-se à decisão; a deliberação pode incluir a definição da agenda e cobrir a fase da implementação, ou centrar-se apenas em encontrar soluções em resposta a problemas predefinidos, que podem colocar-se à escala local, regional ou nacional. Em termos gerais, porém, a deliberação é tão mais útil quanto mais se centre no estabelecimento de prioridades sociais ou propósitos da ação coletiva. Quanto mais técnica a decisão, ou mais complexo o problema enfrentado, exigindo portanto maior acesso e processamento de informação, maior probabilidade há de que a decisão fique mais bem entregue a 
representantes eleitos. Não será, por conseguinte, surpreendente, que os experimentos mais conhecidos de democracia deliberativa com poderes decisórios se tenham fixado a nível local - com destaque para o mecanismo conhecido como "orçamento participativo", liderado pela prefeitura de Porto Alegre, que vem sendo replicado em múltiplas cidades, um pouco por todo o mundo - e se concentrem na alocação de receitas por prioridades sociais estabelecidas deliberativamente e na resolução de problemas tangíveis, com impacto direto sobre a qualidade de vida (a qualidade das escolas locais, a segurança dos bairros, o estado do parque habitacional, a melhoria do sistema de esgotos, etc.), que afetam os cidadãos enquanto consumidores de bens públicos, em cuja definição e em cujos modos de prestação querem ter uma palavra. ${ }^{15}$

A ideia é a de que, a nível local: 1) os cidadãos terão um conhecimento mais próximo das situações relevantes e de como melhorá-las; 2) poderão trazer informação útil para o processo deliberativo e considerar alternativas mais profundamente do que o fariam em processos agregativos menos reflexivos; 3) a deliberação aumenta a disposição e a capacidade deliberativa dos participantes, bem como o seu compromisso para com a implementação de soluções que eles próprios definem; 4) o processo de feedback entre deliberação, decisão, ação, efeito, observação e reconsideração é encurtado, permitindo uma correção mais rápida de estratégias ineficientes. Mas se esses potenciais efeitos positivos se verificam, na prática, e compensam eventuais perdas em perícia técnica, é uma questão empírica, que importa empiricamente estudar. E isso sem esquecer os riscos que se correm, designadamente: a potencial vulnerabilidade das arenas deliberativas ao desequilíbrio de disponibilidade, recursos e poder entre participantes, que desde logo pode determinar quem mais nelas participa; a sua possível instrumentalização por atores externos que as utilizam apenas quando conveniente à persecução de um interesse seu; a sua expectável captura por grupos de interesse, especialmente bem informados e organizados, ou a sua reabsorção pela mesma política clientelar de que se visavam libertar; e ainda eventuais efeitos de balcanização da política, já que esses experimentos constituem e devolvem poder a centenas de grupos, cada um deles focado em assuntos específicos, levantados numa área geográfica particular, o que pode voltar cada área para

A esse respeito, veja-se, por exemplo, Avritzer (2002). 
si, e dificultar a formação de agendas políticas nacionais mais alargadas, bem como a resolução cooperativa de problemas de maior escala. ${ }^{16}$

Com efeito, à escala nacional, a capacidade de os cidadãos continuarem a deliberar entre si sobre as prioridades sociais e os propósitos da ação coletiva - isto é, sobre aquilo que mais importa fazer e a que mais importa alocar recursos públicos - é vital, mas a elaboração e implementação da nova legislação e das políticas públicas que mais eficazmente possam vir a alcançar esses propósitos reveste-se de uma complexidade tal que é de esperar, bem assim como de exigir, que os nossos representantes, indivíduos cuja atividade profissional é conduzir tais processos, deliberem mais informadamente, naveguem melhor os conflitos de interesse inerentes, e tenham maior capacidade para construir compromissos razoáveis entre os grupos e os interesses em contenção. De resto, é importante não esquecer que há muitas questões políticas, diríamos mesmo, a parcela mais substantiva da atividade governamental, em que a deliberação pública alargada não é necessária, e seria mesmo contraproducente, devendo a consideração de alternativas e a própria decisão sobre elas caber, nesses casos, a grupos bastante pequenos ou mesmo a indivíduos exercendo poder em nome de, e portanto também necessariamente responsabilizáveis, perante a população.

Tal não é o caso, porém, quando o que está em causa é a definição de prioridades sociais ou a escolha entre diferentes políticas públicas em setores de atuação do Estado especialmente relevantes para a população: nesses casos, a discussão pública alargada sobre as opções em consideração e outras que se justificasse equacionar desempenha um papel crucial. Na medida, porém, em que, especialmente no caso das políticas públicas, a consideração de al-

${ }^{16}$ Esse perigo é enfatizado por vários autores. John Parkinson, por exemplo, conduziu um estudo com base em experiências deliberativas conduzidas no Reino Unido sobre o sistema nacional de saúde britânico. Considerando-se o sistema de saúde uma instituição "nacional", a decisão de organizar o processo deliberativo, privilegiando-se a representação de interesses territoriais, de nível local, não poderia deixar de ser controversa. É que a escolha da localidade como base para a deliberação tem um impacto não negligenciável sobre as posições e interesses que nela saem representados e ignorados. Parkinson destaca alguns dos problemas advenientes da natureza local da experiência deliberativa: 1) a exacerbação dos problemas com a definição da agenda e a restrição tácita do âmbito da deliberação ao que pudesse ser decidido a nível local; 2 ) a desmotivação dos cidadãos perante a participação em fóruns em que apenas o localmente variável está em discussão; e 3) a dificuldade em levá-los a considerar todas as consequências das orientações políticas em discussão, ou as externalidades positivas e negativas das decisões contempladas, quando a forma de organização e de constituição do fórum deliberativo apela, por si mesma, a uma definição territorial dos interesses (Parkinson, 2006, p. 73 e 96). 
ternativas requer algum conhecimento técnico, senão mesmo a assistência de peritos, tem ganho ascendente a ideia de suplementar os trabalhos das assembleias representativas com a reunião periódica de assembleias de grupos de cidadãos que deliberem e aconselhem os representantes eleitos sobre as orientações das políticas públicas a seguir (Carson e Martin, 1999; Leib, 2004). A ideia tem uma credencial democrática inequívoca: o recrutamento por método aleatório de cidadãos comuns para exercerem funções políticas de importância significativa que caracterizou a democracia ateniense. ${ }^{17}$ Para muitos, é na institucionalização da democracia deliberativa - isto é, na concepção e multiplicação de minipúblicos, compostos por cidadãos que atuam como representantes não eleitos dos demais cidadãos, reunidos para discutir e chegar a um eventual consenso sobre políticas públicas concretas - que devemos concentrar hoje a nossa esperança de reinvenção da política democrática, aqui entendida como uma política de horizontes temporais mais alargados, trocando o sound-bite pelo juízo ponderado, e o jogo de interesses ou o sectarismo político-partidário pela avaliação competente e desapaixonada de cidadãos que agem informadamente em benefício dos seus pares (Fishkin, 1996, p. 162; vide igualmente 1991). Tidos por "esferas públicas mais perfeitas" (Fung, 2003, p. 339), os minipúblicos constituem-se como uma espécie de pequeno paraíso deliberativo, imune às inúmeras deficiências, distorções e manipulações que afetam a deliberação de massas na esfera pública informal mais alargada. "Projetados para serem grupos o suficientemente pequenos para serem genuinamente deliberativos, e o suficientemente representativos para serem genuinamente democráticos" os mini-públicos apresentam-se a público como centros de reabilitação do ideal deliberativo para a vida democrática (Goodin e Dryzek, 2006, p. 219-220).

Seria apressado daqui concluir, porém, que existe um modelo institucional único de deliberação democrática, com regras uniformes de funcionamento, acesso e organização interna, pronto a se aplicar em qualquer ponto do globo ou a qualquer problema de ação coletiva. Pelo contrário, é notável a diversidade de minipúblicos, que se expressa em múltiplos planos. Desde logo, nos propósitos da sua utilização. No contexto de democracias representativas consolidadas, a braços com níveis crescentes de abstenção eleitoral e outras formas de desafeição democrática (a chamada "crise das democracias

Para uma discussão crítica da relação entre as experiências deliberativas recentes e esse legado clássico, embora não tanto o ateniense quanto o das cidades-estado italianas, ver Sintomer (2010). 
representativas"), a sua implementação tipicamente visa aumentar a participação, assim como a transparência e a legitimidade do poder político, dando influência ao cidadão comum sobre um domínio normalmente reservado aos partidos políticos e aos grupos de interesses organizados. Daí a sua focalização em temas como o sistema eleitoral, em cujo desenho os partidos são parte diretamente interessada, ou a sua convocação pelos próprios executivos, quando estão em causa da reforma de políticas públicas com um valor efetivo e simbólico "acrescentado": como é o caso dos serviços nacionais de saúde, pilares fundamentais do Estado Social. Para além dos minipúblicos, que, como o nome indica, envolvem episodicamente apenas um número reduzido de cidadãos, a democracia deliberativa tem-se institucionalizado por via de mecanismos de governança participativa, como é o caso do Orçamento Participativo de Porto Alegre, criado no início da década de 1990, no intuito de pôr cobro a anos de patrocinato político e clientelismo, por meio de um complexo sistema deliberativo e de representação de interesses que permite aos residentes participarem diretamente na definição dos respectivos orçamentos municipais (essa solução institucional foi entretanto alargada a muitas outras cidades dentro e fora do Brasil). Outro exemplo é o sistema de governança das aldeias Panchayat, nos estados de Kerala e Bengala Ocidental, na Índia, com as suas assembleias deliberativas (Gram Sabhas) e conselhos locais de planejamento, igualmente criados para oferecer uma alternativa a um sistema profundamente corrupto e ineficaz (Fung e Wright, 2001, p. 13 e 15).

A sua diversidade da institucionalização da democracia deliberativa também se faz sentir no plano dos temas discutidos. Em alguns desses casos, o tema é estritamente local, noutros de âmbito regional ou mesmo nacional. Em alguns casos, discute-se apenas uma questão, noutros apela-se ao tratamento do maior número de temas possível. Por exemplo, as Assembleias de Cidadãos para a Reforma Eleitoral da Colômbia Britânica (em 2004) e de Ontário (em 2006), duas províncias no Canadá, reuniram algumas centenas de cidadãos, escolhidos aleatoriamente, para redigirem pareceres com sugestões de reforma dos respectivos sistemas eleitorais, posteriormente submetidos a referendo, e são exemplo de um minipúblico organizado para discutir uma só questão de âmbito regional (Warren e Pearse, 2008). Já a proposta para um "Dia Deliberativo" a anteceder eleições nacionais nos Estados Unidos visava justamente ao oposto: incentivar os cidadãos a discutir 
o maior número de questões possível, dos problemas do estado à política externa norte-americana, passando por questões econômicas, ambientais ou culturais (Ackerman e Fishkin, 2004). O estatuto desses minipúblicos nos respectivos sistemas políticos também não é homogêneo. Ainda que na maior parte das vezes o resultado das deliberações tenha um estatuto meramente consultivo, estando a deliberação separada da decisão, existem minipúblicos donde resultam decisões políticas de caráter vinculativo - é o caso dos parlamentos (Bessette, 1994). Mas, se os parlamentos são órgãos autorizados eleitoralmente para, e responsabilizáveis eleitoralmente pelo, exercício do poder, assim não acontece com os minipúblicos de extração extraparlamentar, cuja legitimidade para o exercício de um poder de influência requer outra fundação.

Uma solução possível é a sua representatividade. ${ }^{18}$ Para alguns, eles constituem não tanto uma variante da, quanto uma alternativa à política representativa, já que os cidadãos que os integram falam em seu nome, e se alguém representam, é apenas a si mesmos (Fixdal, 1997). Sendo assim, porém, as conclusões a que esses minipúblicos chegam valeriam apenas para os participantes, e não seriam, como se pretende, extrapoláveis para o público em geral. Com efeito, o elemento público dos minipúblicos, e a força normativa das suas conclusões, parece referir-se menos às condições de publicidade em que nem sempre deliberaram do que ao pressuposto implícito de que os resultados da sua deliberação espelham, representam, ou falam pelo público em geral (algo que a sua designação original, por Robert A. Dahl, dos "minipúblicos" como "minipopulus" capta perfeitamente; veja-se Dahl, 1989, p. 340).

\section{Representação descritiva}

Todavia, não basta atribuir uma função representativa aos minipúblicos. Mais do que atribuir, importa discutir em que base essa alegada representatividade assenta. Certamente não na autorização eleitoral, visto que os cidadãos "representantes" nem são eleitos pelos seus pares, nem ficam a eles ligados pelos mecanismos de responsabilização e de responsividade que, em cada ciclo eleitoral, estruturam a relação entre representados e representantes eleitos. Mais plausível é, portanto, que o caráter representativo dos minipú-

${ }_{18} \mathrm{O}$ argumento feito nesta seção retoma o apresentado em Vieira e Runciman (2008). 
blicos se funde numa concepção diferente de representação, como descrição ou mimese. Isto é, cada minipúblico, se bem constituído, representará uma amostragem fidedigna da forma e do pensar do público como um todo. Há, porém, duas formas possíveis de construir essa amostragem, dependendo do objetivo que com ela se pretenda alcançar: incluir o maior número de perspectivas possível ou incluí-las em estreita proporção à sua presença social. Podemos, assim, ou produzir uma amostragem que seja estratificada proporcionalmente à presença de características tidas por relevantes na população em geral (definindo-se, por exemplo, quotas por idade, gênero, raça, etnia, religião, educação, estatuto, classe, localidade, etc.) ou produzir, muito simplesmente, uma seção demográfica transversal, garantindo que pelo menos uma pessoa de cada grupo socialmente relevante tenha presença garantida. Note-se que a utilização de características sociais para constituir um grupo deliberativo a partir de uma amostra aleatória inicial prescinde de teorias sociais sobre que características importam, assim como da presunção de uma ligação entre características sociais e pontos de vista (sendo a exclusão de critérios como a filiação partidária ou orientação ideológica indicativa do desejo de não tomar as posições e argumentos partidários como ponto de partida para a discussão, privilegiando-se antes o recrutamento do cidadão "independente" e a apresentação de informação relevante por peritos). A escolha entre um e outro método de construção do minipúblico depende do fim a que este se propõe: estabelecer uma plataforma em que grupos de indivíduos abraçando os mais salientes interesses, opiniões e visões numa dada sociedade sejam encorajados a debater determinadas questões de interesse geral, e, possivelmente, a rever as suas posições em consequência disso (mas incorrendo no perigo de a proporcionalidade da representação gerar exclusões de vozes minoritárias e um convite à negociação em razão do diferente poder relativo das partes); ou criar um canal de expressão e de possível influência para visões que o processo político poderia ter de outra forma marginalizado, por serem minoritárias e/ou enfrentarem obstáculos sérios à sua expressão, assim deliberadamente combatendo a influência de desigualdades externas à da melhor razão.

Em qualquer dos casos a concepção de representação subjacente é essencialmente descritiva: fundada não tanto numa "comunalidade" de interesses (que se esperam não estar perfeitamente definidos para se prestarem à transformação deliberativa) quanto em características salientes partilhadas entre 
os cidadãos que constituem o público alargado e os cidadãos selecionados para integrarem o minipúblico (Vieira e Runciman, 2008, p. 110-116). Essas características tendem a ser de ordem sócio-demográfica e, portanto, involuntárias, no sentido de estarem fora do controle imediato da pessoa em questão (por oposição a critérios de identidade mais facilmente mutáveis como, por exemplo, a identificação partidária ou a ideologia política). O pressuposto da seleção de representantes descritivos, sobretudo se pela definição de quotas, é que o seu comportamento será, pelo menos em parte, função dessas características, que são assim tidas por determinantes da probabilidade de esses indivíduos serem portadores de determinadas experiências, atitudes, crenças e valores, e, por conseguinte, de se posicionarem tendencialmente de determinada forma perante a questão colocada à sua apreciação. Opera aqui implicitamente uma espécie de divisão cognitiva do trabalho: dado que a esmagadora maioria das pessoas tem pouca disponibilidade para apreciar uma peça de legislação ou política pública, confia a sua apreciação a pessoas "como ela", na expectativa de que as conclusões a que chegam sejam idênticas "às suas", caso tivessem acesso ao mesmo tipo de informação e despendessem o tempo necessário ao seu processamento.

Se, por um lado, a relevância política das nossas diferentes características sócio-demográficas tem variado muito entre sociedades e ao longo do tempo, por outro lado, a nossa expectativa de que pessoas "como nós" atuem como nós faríamos nas mesmas circunstâncias mantém-se no geral inalterada. Acontece, porém, que tal expectativa enferma de um problema substantivo: o essencialismo. O essencialismo ocorre sempre que tomamos uma característica ou um aspecto da nossa identidade (por exemplo, o gênero) como determinante para a experiência do grupo de indivíduos que partilham essa característica e como definidor do seu posicionamento face a um sem-número de questões. Acontece, porém, que as nossas identidades são cada vez mais múltiplas e entrecruzadas, sendo de esperar a coexistência de, quando não mesmo o conflito entre, perspectivas e posicionamentos diversos num mesmo grupo identitário ou até num mesmo indivíduo. Assim sendo, não é razoável esperar, por exemplo, que as mulheres selecionadas para um minipúblico representem as experiências e visões de todas a outras mulheres que dele não fazem parte, pelo simples fato de serem mulheres. Escusado será a esse título relembrar que diferentes mulheres experienciam a categoria "gênero" e o significado social que lhe é atribuído de forma muito 
diferente, sendo vã a tentativa de encontrar uma experiência ou visão de mulher "autêntica", que pela sua perfeita tipicidade seja "representativa" de todas as demais. Isso coloca dificuldades evidentes à representação descritiva: se nenhuma mulher pode conhecer as experiências de todas as mulheres, com que autoridade pode falar enquanto "mulher"? Com que legitimidade pode falar sobre e em nome das mulheres como um todo? Essas perguntas remetem-nos de imediato para uma outra: Poderão as identidades ser não essenciais, mas ainda assim epistêmica e politicamente relevantes para fundar um laço representativo? A resposta a essa questão depende muito da forma como características como o gênero estejam ou não na base da distribuição de posições numa dada sociedade, e dessa forma afetem ou não o estatuto dos membros do grupo e as suas oportunidades por relação a outros grupos nessa mesma sociedade, eventualmente gerando desigualdades, relações estruturais de poder ou de dominação social duradouras, cuja relação com a característica saliente é patente. Quando assim acontece é expectável que essas relações de poder e dominação se inscrevam na história de vida dos diferentes membros do grupo, dando lugar a um conjunto de experiências similares. Se estas produzem perspectivas similares sobre a realidade social é algo bem menos seguro. Mas essa é também a base em que assenta a expectativa de que a representatividade, em sentido estatístico, gere uma representação além de si, ainda que se reconheça ser excessivo extrapolar que tais perspectivas, mesmo que partilhadas, se traduzam natural e necessariamente num conjunto de interesses ou de objetivos comuns (Young, 2000). É que a passagem da perspectiva ao interesse coletivo, reconhecido pelo grupo, e fora dele, enquanto tal, exige construção e mediação política - seja por partidos, por associações ou por movimentos. Não será, pois, por acaso que os representantes descritivos que habitam os minipúblicos tendem a resistir à sua definição enquanto tal, insistindo que falam apenas em seu próprio nome, ou da sua própria perspectiva. A esperança de quem os seleciona é que essa perspectiva fale para além deles. Mas, se em determinadas condições isso pode acontecer, é também claro que qualquer invocação de um laço representativo mais forte continuaria dependente da ativação, da mobilização e da efetiva interlocução com o grupo de indivíduos alegadamente representado, cuja possibilidade de objeção ao que é feito pelo representante descritivo em seu nome é crucial para que possamos falar de um vínculo representativo democrático. 


\section{Representação de perspectivas e representação discursiva}

A ideia de uma representação de perspectivas apenas tem acérrimos defensores nos teóricos da democracia deliberativa. Isso acontece porque, na sua ótica, a representação de perspectivas tem uma clara vantagem sobre a representação de interesses: se a representação proporcional de grupos de interesse é um convite à inflexibilidade e à negociação estratégica, já a representação de perspectivas, pela sua flexibilidade intrínseca e não desdobramento necessário em interesses, deixa aos representantes, sejam eles leigos ou profissionais, uma maior liberdade de pensarem por si mesmos e de mudarem as suas opiniões em interação com os demais.

Mas, no momento em que nos começamos a centrar na representação da pluralidade de "perspectivas", "opiniões" ou mesmo "discursos" existentes numa dada sociedade, começamos também a mover-nos numa nova direção, em que a deliberação parece estar mais ao serviço da racionalidade da elaboração de políticas públicas do que da emancipação e transformação das condições de vida dos cidadãos. É de resto notória a "despersonalização" progressiva do objeto representado entre os defensores da representação de "perspectivas", “opiniões” ou "discursos”. Uma "despersonalização" que chega ao ponto de nos fazer crer que os participantes valem apenas pelas "perspectivas", "opiniões" e "discursos" com que contribuem para a deliberação, e que as "perspectivas", "opiniões" e "discursos" de que se fala vivem majoritariamente numa espécie de livre flutuação, isto é, sem qualquer radicação em pessoas reais, com interesses, valores e concepções diversas da melhor sociedade, senão mesmo abertamente conflitantes: "Para a racionalidade da elaboração das políticas públicas", dizem-nos John Dryzek e Simon Niemeyer, "todos os discursos relevantes devem ser representados - independentemente de quantas pessoas os subscrevam. A racionalidade pode mesmo beneficiar da presença de um ponto de vista que ninguém subscreva" (Dryzek e Niemeyer, 2008, p. 7, tradução dos autores). E, quando assim se advoga que os "pontos de vista" não necessitam de ser representados por um número de representantes proporcional ao número de cidadãos que efetivamente os abraçam, mas apenas de estar presentes no minipúblico em nome da racionalidade, torna-se questionável se as características sócio-demográficas em cuja base as amostras estatisticamente representativas são construídas serão a melhor forma de decidir quem representa o quê. É que, reificados os "discursos", os seus melhores representantes serão aqueles que os organizadores do 
minipúblicos tecnicamente considerem ser porta-vozes mais aptos para os discursos que tenham tecnicamente identificado como relevantes para a discussão de determinada matéria. E assim, passo a passo, a ciência social vai-se substituindo ao processo político, e o potencial radical da democracia deliberativa esvazia-se às mãos de uma nova tecnificação da política, que transforma a deliberação num dispositivo essencialmente conservador, colocado ao serviço dos requisitos de consulta pública que recaem sobre os governos (Dryzek e Niemeyer, 2008, p. 11 e 37).

Tanto a representação de "perspectivas" quanto a representação de "discursos" admitem, senão mesmo exigem, uma certa independência dos representantes em relação aos representados. ${ }^{19}$ Isso acontece não apenas porque as "perspectivas" e os "discursos" têm uma relação complexa e mediada com as pessoas e grupos que os subscrevem ou a que eles se referem, mas também porque é possível partilhar uma "perspectiva" ou "discurso" com alguém, sem que necessariamente se deseje um mesmo resultado num dado cenário (Vieira e Runciman, 2008, p. 115). E, se é certo que, resultando a diversidade de perspectivas da localização de cada grupo na estrutura de dada sociedade e das experiências que essa localização desencadeia, se torna mais difícil para um elemento externo ao grupo adotar a sua perspectiva, ou ponto de vista sobre o mundo, do que adotar o seu discurso, em ambos os casos a empatia ou a identificação tendem a ser invocadas como base possível de um vínculo representativo.

\section{Representação como "defesa de causas"}

É, de resto, na identificação que se funda uma concepção alternativa à representação descritiva, a representação como "defesa de causas" ou "ad-

\footnotetext{
${ }^{9}$ Um certo nível de independência é essencial à relação de representação política democrática. Recorde-se, a este título, que as "preferências" e mesmo os "interesses" dos representados não são prévios ao, mas antes co-construídos no, próprio processo de representação, em que tanto representantes quanto representados devem ser tratados como agentes ativos, em interlocução próxima. A falta de um fechamento ou de uma perfeita identidade entre representante e representado (e as respectivas posições) é essencial ao processo democrático, na medida em que ela cria uma necessidade de contínua renegociação da sua relação. O problema surge quando a autonomia concedida ao representante é tal que se constrói a expensas da do representado. Assim parece acontecer na representação discursiva, quando os representantes são tidos como responsabilizáveis perante os discursos que representam (pela obrigação em comunicar em termos que façam sentido no âmbito do discurso), mas não tanto perante as pessoas que esses discursos constroem de determinada forma (por exemplo, como vítimas de injustiça, destituídas da autonomia necessária à auto-representação, uma imagem - e uma realidade - amiúde reforça).
} 
vocacy" (Urbinati, 2000). Esta combina um compromisso "apaixonado" do representante com as causas dos seus constituintes à sua relativa autonomia de ação em sua defesa. A tônica é aqui colocada não tanto nas características eventualmente partilhadas entre representante e representado quanto na sua proximidade às suas mundivisões e preocupações. Assim naturalmente se conclui que aquilo que é necessário a um bom defensor da causa não é tanto uma "identificação existencial" quanto "uma identidade de ideais e projetos", e uma capacidade efetiva para lhe conferir uma visibilidade e acutilância tais que obriga os demais a uma reação (Urbinati, 2000, p. 777). O conceito de "advocacy", que é na sua raiz um conceito do campo legal, coloca a tônica na capacidade argumentativa e persuasiva do representante, uma capacidade que é tida por colmatar a incapacidade de determinados grupos falarem por si mesmos ou pelo menos falarem numa voz que se consiga fazer ouvir. O problema da representação enquanto "advocacy" é que, quando desligada de uma exigência de interlocução e desenvolvimento de capacidades agenciais nos representados, pode facilmente desaguar no paternalismo ou na mera caridade.

A representação, e mais assim a representação democrática, requer algo mais do que atuar em benefício de outrem ou prestar-lhe um serviço, mesmo que sob sua instrução: ela exige que o representante confira uma presença ao representado na sua ação sobre a qual este último possa exercer alguma forma de controle, desde logo pela objeção à presença que lhe é dada (Vieira e Runciman, 2008, p. 65-83). Disso se parecem esquecer por vezes os proponentes de entendimentos da representação tributários da noção de "advocacy", como o são a representação "virtual", "presuntiva" ou por simples "afinidade". ${ }^{20}$ Quer isso dizer que noções de representação mais "interpretativas" ou "construtivas" não têm lugar numa democracia? A resposta é claramente negativa. É que muitos casos há em que a representação de um grupo depende decisivamente da intervenção de uma agência "externa" (aliás, na vasta maioria dos casos politicamente relevantes, os grupos são tão vastos, diversos ou difusos, que seriam incapazes de falar por si mesmos sem a mediação da representação, necessitando igualmente de ser representados na objeção à presença que lhes é dada por determinados representantes, incluindo os eleitoralmente autorizados). E necessitando

${ }_{20}$ Vejam-se, entre outros, Avritzer (2007) e Lavalle, Houtzager e Castello (2007). 
também de uma interpretação da posição e dos interesses do grupo sujeita à contestação por representantes que dão uma presença alternativa à posição e aos interesses desse mesmo grupo (é importante assinalar, a esse respeito, que, ao contrário de uma sugestão recorrente, os interesses não são uma categoria objetiva e pré-política, emanando diretamente da "realidade" socioeconômica, mas antes coconstruídos no processo de representação). O fato de o grupo não poder falar por si, enquanto tal, não autoriza os seus eventuais representantes a assumir publicamente o lugar do grupo pela simples substituição ou omissão das vozes que o integram. Pelo contrário, as dimensões relacionais da representação ganham aqui uma nova acuidade, e o esforço, que deve ser contínuo, de prestar contas ao grupo pela sua ação deve contribuir para o reforço da mobilização e da agência do próprio grupo, revelando-se ultimamente decisivo para o autodesenvolvimento e a autodeterminação quer do grupo, quer dos seus membros, inclusive na escolha de quem melhor os representa. Disso mesmo nos dá conta o estudo realizado por John Parkinson aos minipúblicos organizados na Inglaterra para discutir a reforma do sistema nacional de saúde. Alguns dos seus principais utentes, os cidadãos portadores de deficiência, temeram a diminuição da sua voz nos minipúblicos, porque, pela sua própria natureza, muitas das deficiências, com destaque para as deficiências mentais, adquirem "voz" apenas pela mediação de ativistas e de redes de defesa ou promoção pública dos seus direitos, que haviam sido total ou parcialmente excluídas de participação nos minipúblicos, na sua tentativa de privilegiar a "opinião imparcial" do cidadão "independente", não partidarizado e não previamente "ativado" (ver Parkinson, 2006, p. 71).

\section{A natureza contrafactual dos minipúblicos}

Mas os problemas de representatividade dos minipúblicos não param por aqui. Os minipúblicos são uma espécie de abrigo seguro da deliberação. Neles se promove o diálogo, a troca de ideias, o respeito mútuo e a comunicação simétrica. Isso é feito na expectativa de que o juízo dos cidadãos seja ativado, as suas crenças se tornem mais bem informadas, as suas opiniões e posições finais sejam mais razoáveis do que as de partida, porque mais capazes de tomar as preocupações e os interesses das demais pessoas em linha de consideração. Tudo isso se vislumbra como desejável, mas tudo isto gera também um iniludível hiato entre os membros informados e reflexivos 
do minipúblico e os membros menos informados e menos reflexivos do público em geral. Porque produto de um processo de deliberação artificial e perfeitamente controlado, a opinião eventualmente expressa pelo minipúblico assumirá sempre uma natureza contrafatual. Noutras palavras, ela não representará a opinião pública tal como ela é, mas tal como ela poderia ser, se os procedimentos na esfera pública alargada fossem genuinamente deliberativos, e não enfrentassem os problemas de escala, complexidade, falta de acesso à informação ou de conhecimento, assimetria de poder e de oportunidades para falar e se fazer ouvir, que permeiam o público em geral. Acresce a isto que se os minipúblicos tendem a ser desenhados para representar cidadãos "comuns" - pelo que se entende normalmente cidadãos com "preferências" potencialmente maleáveis, e portanto não partidários ou ativistas - a verdade é que é duvidoso que sejam bem sucedidos nesse propósito. Para percebermos por que basta olharmos para os seus inputs e outputs, respectivamente. Ainda que os elementos do minipúblico sejam aleatoriamente selecionados, a sua eventual presença nas sessões deliberativas é voluntária, encontrando-se portanto dependente da aceitação prévia de um convite. $\mathrm{E}$ as experiências conduzidas demonstram que os cidadãos mais propensos a aceitar esse convite são os cidadãos mais ativos, cívica e politicamente, que têm maior conhecimento e interesse na questão em discussão, e maior confiança também na eficácia da participação política; ou, muito simplesmente, os cidadãos com maior disponibilidade de tempo (Mansbridge, 1980). Assim sendo, a capacidade de atração de outros segmentos da população, designadamente os "trabalhadores pobres", fica dependente da capacidade persuasiva dos organizadores dos minipúblicos ou de incentivos extra à sua participação, designadamente o pagamento, que constitui um fato novo de enviesamento. Mas o distanciamento face ao "cidadão comum" verifica-se também pelo próprio efeito do processo deliberativo, na medida em que através dele se gera uma possível transformação do cidadão "inativo" pelo cidadão "ativo" ou "ativado", e uma pretensão de representação do primeiro pelo segundo. Quer tudo isso dizer que um minipúblico não pode ser representativo? Não necessariamente. Mas, se a deliberação institucionalmente controlada, pela sua própria atipicidade, contribuir para minorar a representatividade original dos representantes descritivos, o laço representativo, a existir, tem de encontrar outra fundação para além da sua composição. 
Um candidato forte é a ideia de responsabilização, tal como ramificada do termo inglês "accountability". Os minipúblicos ou painéis consultivos não são eleitos, nem portanto eleitoralmente responsabilizáveis, encontrando-se, assim, imunizados relativamente à sanção por comportamentos não representativos, o que dá razão para preocupação. Mas uma das suas funções primordiais é, precisamente, a de fornecer razões ou justificações ("accounts") para as decisões que venham a tomar, razões essas que possam ser divulgadas ao público em geral com vista a assegurarem o seu apoio para o curso de ação deliberativamente favorecido. Determinar-se-á por via desta adesão retrospectiva se o painel efetivamente chegou, por meio da racionalização discursiva, às preferências reais, mas anteriormente apenas latentes, do público em geral. Todavia, no exato momento em que a aprovação do público é explicitamente solicitada - por exemplo, por via de um referendo - sobre a decisão a que o painel consultivo chegou, a deliberação é destilada numa questão quantas das vezes binária, de sim ou não, e uma nova forma de representação entra imediatamente em jogo. A representação passa agora a assentar na possibilidade de objeção por parte dos representados, e a representatividade do painel vinga-se agora não pela sua composição diversificada, nem pela superior racionalidade das decisões alcançadas, mas antes pelo consentimento que a maioria do eleitorado lhe preste, ou não, no âmbito de uma competição eleitoral por votos, que dificilmente se aproximará das condições ideais de deliberação (Vieira e Runciman, 2008). E é bem possível que o corpo deliberativo, aleatoriamente reunido, tenha chegado a conclusões diferentes daquelas que as eleições venham a registrar, como aliás veio a suceder em diversas ocasiões. ${ }^{21}$

\section{Imparcialidade versus generalidade: os perigos de despolitização}

Para além da relação entre o minipúblico e o público em geral ser, como vimos, longe de linear, coloca-se igualmente a questão de saber qual a relação entre os minipúblicos e os representantes eleitos para governar o público em

\footnotetext{
Em 2005, a proposta da Assembleia de Cidadãos para a Reforma Eleitoral de British Columbia, no Canadá, foi chumbada quando submetida ao voto popular (obteve $57.7 \%$ dos votos quando precisava de $60 \%$ ). Quatro anos mais tarde, viria novamente a ser rejeitada, agora por números mais expressivos (apenas 38.7\% de votos a favor). Ainda no Canadá, mas agora na província de Ontário, uma Assembleia de Cidadãos criada à imagem da de British Columbia, viu igualmente rejeitada a sua proposta em 2007 (63\% de votos contra). Na Europa, em 2006, um candidato do PASOK, escolhido por uma amostra de cidadãos da cidade de Marousi, perdeu, meses depois, as eleições a que concorreu (Sintomer, 2010, p. 480).
} 
geral. Essa segunda dimensão assume especial relevo se tivermos em atenção o fato de alguns proponentes da democracia deliberativa defenderem que certa despolitização é necessária à realização do ideal deliberativo, sendo feito um apelo direto à utilização dos minipúblicos para produzirem esse efeito de despolitização. Nessa linha, Philip Pettit defende que, "se é realmente suposto que a deliberação domine a vida pública, então não há opção senão despolitizar as decisões políticas de várias formas" (Pettit, 2004, p. 64). Configura-se nesse apelo de Pettit à "despolitização" um confronto entre, por um lado, a política institucionalizada, de raiz político-partidária, e lógica agregativa e majoritária, e, por outro, uma contrapolítica, não partidária, de lógica consensual, restaurando-se assim a divisão moral entre eleição e deliberação que neste artigo se criticou. A ideia por detrás da dicotomia é clara: os partidos e seus líderes não são agentes deliberativos, antes desencorajam a deliberação, designadamente entre militantes e simpatizantes, cujas posições são não deliberativas por definição. Estando a competição partidária longe de gerar um "julgamento pela discussão", a deliberação tem de ser deixada a cidadãos "leigos", cujo objetivo não é clarificar as razões aduzidas a favor ou contra posições partidárias, mas antes discutir a questão para além delas, assim chegando a uma opinião pública mais informada, com a autoridade epistêmica e moral sobre os decisores políticos (Rosenblum, 2008, p. 298). Face a esse entendimento da relação entre democracia eleitoral e democracia deliberativa - que perde inteiramente de vista o papel deliberativo dos partidos na ativação da opinião pública, ao constituírem alternativas de ação coletiva e convidarem os eleitores a conceberem os seus interesses pela óptica de posições de interesse pré-generalizadas - não é de estranhar que os governos procurem legitimidade para a sua ação não tanto no reforço do seu papel na deliberação democrática quanto na organização de minipúblicos, alimentando, por vezes, um entendimento da política como uma prática essencialmente cognitiva, de busca de soluções para problemas. O resultado desse apelo a uma legitimação externa é complexo. Se a conclusão do minipúblico for na direção contrária à dos decisores políticos, as duas formas de representação, eleitoral e descritiva, podem entrar em conflito, restando aos decisores ou ignorar o minipúblico ou colocar a decisão à população em geral, via referendo. $\mathrm{O}$ caráter meramente consultivo normalmente reservado aos minipúblicos espelha a superioridade do vínculo eleitoral, com a possibilidade que ele comporta de objeção última ao representante 
pela não recondução no cargo - uma superioridade que, no entanto, pode conduzir os minipúblicos à frustração. ${ }^{22}$ Já quando a conclusão do minipúblico serve de base a uma política pública que se sustenta nessa consulta alargada a frustração pode ser outra, e do público em geral, por se tornar mais difícil penalizar um responsável pelos eventuais maus resultados da sua implementação. O uso estratégico de experiências deliberativas controladas para combater a influência política dos interesses organizados e dos partidos pode ter ainda outros efeitos colaterais. Quando a deliberação de questões políticas importantes é deslocalizada para minipúblicos, os parlamentos correm o risco de se verem esvaziados enquanto câmaras deliberativas, restando-lhes aceitar ou rejeitar um resultado produzido exteriormente: produz-se assim uma dissociação entre deliberação e decisão, que alguns põem ao serviço do propósito, mais do que questionável, da despolitização (Pettit, 2004, p. 54-55).

Não devemos igualmente ignorar o potencial antidemocrático (porque racionalista, logo elitista) que a proliferação de minipúblicos pode acarretar (Urbinati, 2010). Os minipúblicos podem ser manipulados por quem os reúne, ou autoriza, para legitimarem, ou obterem maior apoio popular, para decisões controversas que as elites, à partida, favorecem. É que a formação da agenda, o enquadramento das questões a ser discutidas, e o próprio menu de alternativas sob discussão não são muitas das vezes parte do próprio processo político interno aos minipúblicos, mas antes prerrogativa dos seus organizadores e/ou mediadores. Disso resulta que os participantes em minipúblicos possam atuar como uma espécie de cidadãos tutelados, seguindo procedimentos que outros definiram, para julgarem alternativas políticas para cuja estruturação pouco ou nada contribuíram (Della Porta, 2005). Cidadãos que supostamente personificam o envolvimento dos demais no processo político, ao mesmo tempo podem consubstanciar esse envolvimento em mera passividade e deixar potencialmente intocadas as configurações de poder político, social e econômico dominantes. Recorde-se, por exemplo, que em situações em que as decisões coletivas que a deliberação dos minipúblicos informa

22 Um exemplo ilustrativo disto é a recente iniciativa da Comissão Europeia conhecida por "Consulta aos Cidadãos Europeus", em que painéis de cidadãos de todos os países membros da União Europeia deliberam durante um fim de semana sobre questões políticas relevantes, escolhidas anteriormente por alguns deles, e cujas conclusões são posteriormente dadas a conhecer aos representantes políticos em Bruxelas (Comissão e Parlamento Europeu). Para mais informações, vide http://www.consulta-aos-cidadaos-europeus.eu/ 
impactam e/ou obrigam muito assimetricamente diferentes grupos dentro da população - visto que uns têm uma possibilidade de opting-out de que outros não usufruem -, a equidade final da decisão pode depender menos de uma deliberação mais inclusiva do que de uma ação dirigida à proteção dos mais vulneráveis (Shapiro, 2003, p. 29-30). Não é, pois, desprovida de riscos, e riscos sérios, a tendência para a recondução da democracia participativa, mesmo que na sua vertente estritamente deliberativa, à participação dos cidadãos em experimentos deliberativos que agentes governamentais ou a própria administração promovam.

Há ainda outro risco que a proliferação de minipúblicos comporta, e para que importa desde logo alertar. Dados empíricos entretanto recolhidos dizem-nos que os cidadãos mais dispostos a participar em minipúblicos são os cidadãos alienados da "política do costume", e do seu caráter "partidário", no duplo sentido de ser de parte e de tomar parte ${ }^{23}$ - cidadãos avessos ao poder e à competição político-partidária que, mais do que participar efetivamente no exercício do poder, ou que afetar a sua distribuição, pretendem controlá-lo, torná-lo mais transparente, mais racional, mais imparcial. A promessa que a democracia deliberativa encerra - a de oferecer soluções moralmente justificáveis e racionalmente produzidas para problemas políticos complexos - vai de encontro às suas expectativas de transformação da democracia num regime de consensos. Todavia essa visão "racionalizante" da política, que da política faz prática cognitiva, e dos participantes uma comunidade paracientífica, buscando resultados políticos "certos", ou de cidadãos-juízes, buscando um veredicto imparcial, ${ }^{24}$ pode trazer consigo o perigo importante, já acima enunciado, da despolitização, e pôr em causa o próprio dínamo da política democrática. É que o conflito de interesses e entre diferentes visões de sociedade não é apenas definidor da nossa existência política: ele é constitutivo da deliberação pública democrática, ou seja, “o conflito trabalhado de forma democrática, com abertura e persuasão, é

3 Delli Carpini, Cook e Jacobs (2004).

${ }^{24}$ Quando a juízes ou jurados é pedido que emitam juízos de natureza legal, é-lhes pedido que o façam como terceiras partes a quem é pedido que avaliem caracterizações diferentes da natureza, conteúdo e intenções por detrás de acções passadas. Quando, por contraste, deliberamos sobre matérias políticas, fazemo-lo como partes interessadas, tentando encontrar a melhor forma de realizar objetivos partilhados. Como efeito, quando ligamos com as incertezas associadas com aquilo que mais possa contribuir para a realização do bem comum, as virtudes associadas com a imparcialidade podem impedir o bom juízo e ameaçar as relações que nos permitem deliberar em conjunto. 
o que faz com que a democracia funcione" (Pitkin e Shumer, 1982, p. 47; tradução dos autores). Logo, o desejo de uma política livre de antagonismos, que produza soluções definitivas, e elimine mesmo o desacordo razoável politicamente relevante, representa, no seu âmago, uma recorrente pulsão antidemocrática, cujos efeitos, no passado, são bem conhecidos. Como Nadia Urbinati corretamente sublinha, "não é retirando assuntos politicamente controversos do debate político e delegando-os em comitês de peritos ou cidadãos que a deliberação pode servir a causa da democracia, mas antes mantendo os processos de juízo e formação da vontade abertos ao escrutínio e à revisão, a arena política aberta a visões e grupos políticos em competição" (Urbinati, 2010, p. 84-85; tradução dos autores). A solução não é, pois, abandonar a democracia deliberativa, entendida como um sistema de palcos deliberativos imperfeitos, é certo, mas plurais e comunicantes, a favor da deliberação supostamente mais democrática, porque remetida para uns quantos minipalcos perfeitamente controlados. É precisamente nos nexos entre comunicação e representação, e, dentro da primeira, entre os vários polos imperfeitamente deliberativos que povoam a esfera pública alargada, que se gera a legitimidade da democracia deliberativa.

\section{Conclusões}

Neste artigo revisitamos o conceito de democracia deliberativa, bem como experimentos recentes na sua implementação, com o objetivo de determinar os desafios e as perspectivas de futuro com que esse modelo de democracia hoje se confronta. Uma das ideias-chave que resulta da análise apresentada é a de que a relação entre deliberação e negociação deve ser reequacionada, abandonando-se quer uma visão higienizante da política (em que à "pura" deliberação racional orientada para o bem comum se opõe a "contaminada" luta estratégica em torno de interesses próprios), quer uma posição que reduza a deliberação a uma subcategoria da negociação. ${ }^{25}$ A nossa escolha recai antes sobre uma concepção de política democrática em que a deliberação pode ajudar a transformar outros mecanismos não menos essenciais aos trabalhos da democracia, não se reduzindo a eles, mas também não podendo substituí-los sem mais. Nem todas as questões políticas podem, ou sequer devem, ser deliberativamente tratadas: em casos

${ }^{25}$ Concretamente, uma forma não coerciva de negociação. Vide, por exemplo, Mansbridge et al. (2010). 
de grande complexidade técnica, por exemplo, se a definição das prioridades públicas deve ainda ser deliberativamente tratada, já no tratamento de tecnicidades respeitantes à sua implementação o recurso à deliberação democrática pode ser uma solução menos adequada do que o recurso a representantes especializados. Por outro lado, é importante, na deliberação, ter em conta quem diz o quê. Uma mesma ideia, um mesmo argumento produz um efeito completamente diferente sobre a audiência consoante as características e a credibilidade de quem o enuncia. Ignorar as desigualdades estruturais (socioeconômicas, de gênero, etnia, etc.) e performativas dos participantes em assembleias deliberativas é negar a factualidade do político - feito por, em nome de, e para pessoas e grupos realmente existentes. Uma situação deliberativa processualmente perfeita, e impondo padrões discursivos rígidos, pode perfeitamente apenas refletir e mesmo ampliar situações de desigualdade estrutural que lhe são externas.

A deliberação assim redefinida emerge enquanto uma dimensão imprescindível da nossa vivência política democrática quotidiana, intra e extrainstitucional, que, ao entrecruzar-se com outros componentes democráticos, idealmente os modifica. Tal como a negociação estratégica pode adquirir uma legitimidade acrescida se for deliberativamente filtrada, também uma manifestação de rua pode produzir efeitos deliberativos, mesmo onde argumentos não sejam aduzidos, por chamar a atenção para uma questão excluída da agenda política, assim como adquirir um significado e alcance políticos maiores se acompanhada por um discurso mobilizador. A deliberação, incluindo a deliberação mobilizada sobre as diferentes opções políticas e os diferentes argumentos que os partidos políticos trazem a público, não apenas presume que representantes e representados contribuam ativamente para a definição de alternativas de ação coletiva como também promete ajudar a torná-los mais conscientes das várias dimensões e formas de olhar um mesmo problema, com vista à decisão sobre o melhor curso de ação coletiva. Por contraposição à deliberação exclusivamente intragrupo, a exposição a visões conflitantes pode promover um melhor entendimento dessas visões, dos interesses e das razões que as informam, o que vem potencialmente possibilitar que se alcance um compromisso ou mesmo acordo razoável entre partes. Esse acordo não deve ser identificado com um consenso racional final, produto de um juízo imparcial, impessoal e desinteressado, que seria para a política aquilo que a sentença é para o julgamento, não fora em política legítima - e 
mais do que isso, necessária - a contraposição de diferentes visões do bem de todos e do interesse de cada um.

Como o trabalho recente sobre o percurso teórico-prático da democracia deliberativa tem vindo a sublinhar, o seu potencial radical foi-se perdendo à medida que voltamos atenções, quase em exclusivo, para a deliberação democrática - isto é, para a melhor forma de institucionalizar os exigentes pressupostos processuais de uma situação discursiva ideal em palcos conjuntamente projetados pelo administrador/moderador e pelo cientista social (Chambers, 2009). Com esse centrar de atenções na reunião episódica de cidadãos em fóruns deliberativos artificiais, cujo impacto sobre a participação política dos cidadãos em geral é duvidoso, descuramos as condições em que a esmagadora maioria dos outros cidadãos chega às suas opiniões e formula as suas "preferências" políticas. Os efeitos colaterais desse movimento têm sido de monta: a entronização do cidadão-juiz, independente e imparcial, por contraposição ao cidadão-ator, partidário ou ativista; certa despolitização da política democrática, e deslegitimação da sua natureza agonística, a favor de uma maior "racionalização" (senão de uma nova "tecnificação") das questões de interesse público; uma quase completa despromoção do antagonismo, desde logo o político-partidário, como motor essencial ao "julgamento por discussão"; e uma desatenção a hierarquias de influência, riqueza e poder instaladas, que nenhum paraíso deliberativo, por simétrico e igualitário que seja, poderá remover.

O desafio perante nós, e que este artigo procurou articular, consiste em integrar mais satisfatoriamente a dimensão dupla da democracia: deliberativa e agregativa. Se a democracia estimula o desenvolvimento de visões de parte, sendo pela sua própria natureza, agonística e politicizante, e se a participação política tem o duplo significado de fazer parte de (inclusão) e de tomar partido (dialética política), então é nos mecanismos necessários à promoção de um melhor "partidarismo", não na promoção de uma independência desinteressada e equidistante, que deve atuar primeiramente a deliberação. Enquanto alguns deliberacionistas apelam a que "as queixas dos cidadãos comuns se façam ouvir longe do tumulto da discussão popular e longe mesmo do teatro do debate parlamentar" (Pettit, 1997, p. 196), nós deixamos aqui o apelo contrário. Que onde eles veem tumulto, nós reencontremos a criatividade, a inovação e a energia disruptiva que apenas um meio de comunicação irrestrita pode gerar. Que onde eles veem teatro, ou um palco a abandonar, 
porque tomado pela retórica plebiscitária vazia, nós vejamos o desafio de repensar os procedimentos, as instituições e os incentivos que possam vir a contribuir para uma interlocução entre cidadãos, media e elites políticas mais envolvente, inquisitiva e informada.

\section{Referências}

ACKERMAN, Bruce \& FISHKIN, James (2004). Deliberation day. New Haven: Yale University Press.

ARISTÓTELES (1992). Política. Lisboa: Vega.

ARROW, Kenneth (1951). Social choice and individual values. New York: John Wiley and Sons.

AVRITZER, Leonardo (2002). Democracy and the public space in Latin America. Princeton: Princeton University Press.

(2007). "Sociedade civil, instituições participativas e representação: da autorização à legitimidade da ação". Dados, n. 50, p. 443-464.

BAERT, Patrick \& SILVA, Filipe Carreira da (2010). Social theory in the twentieth century and beyond. Cambridge: Polity Press.

BESSETTE, Joseph (1980). "Deliberative democracy: the majority principle in republican government", em GOLDWIN, Robert \& SHAMBRA, William (eds.). How democratic is the Constitution?. Washington: American Enterprise Institute.

(1994). The mild voice of reason: deliberative democracy \& American national government. Chicago: University of Chicago Press.

BOHMAN, James (1998). "Survey article: the coming of age of deliberative democracy”. The Journal of Political Philosophy, v. 6, n. 4, p. 400-425.

CARSON, Lyn \& MARTIN, Brian (1999). Random selection in politics. Westport: Praeger.

CHAMBERS, Simone (2009). "Rhetoric and the public sphere. Has deliberative democracy abandoned mass democracy?". Political Theory, v. 37, n. 3, p. 323-350.

COHEN, Joshua (1986). "An epistemic conception of democracy". Ethics, n. 97 , p. 26-38.

(1989). "Deliberative democracy and democratic legitimacy", em HAMLIN, Alan \& PETTIT, Philip (eds.). The good polity. Oxford: Blackwell.

(1997). "Deliberation and democratic legitimacy", em BOHMAN, 
James \& REHG, William (eds.). Deliberative democracy: essays on reason and politics, Cambridge: MIT Press.

DAHL, Robert A. (1989). Democracy and its critics. New Haven: Yale University Press.

DALTON, Russell; CAIN, Bruce \& SCARROW, Susan (2003). Democracy transformed?. Oxford: Oxford University Press.

DAMÁSIO, António (1995). Descartes' error: emotion, reason, and the human brain. New York: Harper Perennial.

DELLA PORTA, Donatella (2005). "Making the polis: social forums and democracy in the global justice movement". Mobilization, n. 10, p. 73-94. DELLI CARPINI, Michael X.; COOK, Fay Lomax \& JACOBS, Lawrence R. (2004). "Public deliberation, discursive participation, and citizen engagement: a review of the empirical literature". Annual Review of Political Science, n. 7, p. 315-344.

DEWEY, John (1927). The public and its problems. New York: Holt.

DRYZEK, John S. (1990). Discursive democracy. Cambridge: Cambridge University Press.

(1996). Democracy in capitalist times: ideals, limits, struggles. Oxford: Oxford University Press.

(2002). Deliberative democracy and beyond: liberals, critics, contestations. Oxford: Oxford University Press.

DRYZEK, John S. \& NIEMEYER, Simon (2008). "Discursive representation”. American Political Science Review, n. 102, p. 481-493.

ELSTER, Jon (1986). "The market and the forum: three varieties of political theory”, em ELSTER, John \& HYLAND, Aanund (eds.). Foundations of social choice theory. Cambridge: Cambridge University Press.

FISHKIN, James (1991). Democracy and deliberation: new directions for democratic reforms. New Haven: Yale University Press.

(1996). The voice of the people: public opinion and democracy. New Haven: Yale University Press.

FISHKIN, James \& LUSKIN, Robert (2000). "The quest for deliberative democracy”, em SAWARD, Michael (ed.). Democratic innovation. London: Routledge.

FIXDAL, Jon (1997). "Consensus conferences as 'extended peer groups". Science and Public Policy, v. 24, n. 6, p. 366-376.

FUNG, Archon (2003). “The voice of the people: public opinion and 
democracy". The Journal of Political Philosophy, v. 11, n. 3, p. 338-367. (2004). Empowered participation: reinventing urban democracy. Princeton: Princeton University Press.

FUNG, Archon \& WRIGHT, Eric Olin (2001). "Deepening democracy: innovations in empowered participatory governance". Politics \& Society, v. 29 , n. 1 , p. $5-41$.

GARSTEN, Bryan (2006). Saving persuasion. Cambridge: Harvard University Press.

GOODIN, Robert E. (2000). "Democratic deliberation within”. Philosophy and Public Affairs, v. 29, n. 1, p. 81-109.

(2003). Reflective democracy. Oxford: Oxford University Press.

GOODIN, Robert E. \& DRYZEK, John (2006). "Deliberative impacts: the macro-political uptake of mini-publics”. Politics \& Society, v. 34, n. 2, p. 219-244.

LAVALLE, Adrian Gurza; HOUTZAGER, Peter \& CASTELLO, Graziela (2007). "Political representation and civil organizations: new forms of mediation and the challenges for legitimacy". Revista Brasileira de Ciências Sociais, n. 3, p. 1-31.

GUTMANN, Amy \& THOMPSON, Dennis (2004). Why deliberative democracy? Princeton: Princeton University Press.

HABERMAS, Jürgen (1985). "Civil disobedience: litmus test for the democratic constitutional state”. Berkeley Journal of Sociology, n. 30, p. 95-116.

(1996). Between facts and norms: contributions to a discourse theory of law and democracy. Cambridge: Polity Press.

JAMES, Michael (2008). "Descriptive representation in the British Columbia Citizens' Assembly”, em WARREN, Mark \& PEARSE, Hilary (eds.). Designing deliberative democracy: the British Columbia Citizens' Assembly. Cambridge: Cambridge University Press.

KNIGHT, Jack \& JOHNSON, James (1994). “Aggregation and deliberation: on the possibility of democratic legitimacy". Political Theory, v. 22, n. 2, p. 277-296.

KRAUSE, Sharon R. (2008). Civil passions: moral sentiments and democratic deliberation. Princeton: Princeton University Press.

LEIB, Ethan (2004). Deliberative democracy in America: a proposal for a popular branch of government. University Park: Pennsylvania State University Press. 
LUSKIN, Robert C.; FISHKIN, James S. \& JOWELL, Roger (2002). "Considered opinions: deliberative polling in Britain". British Journal of Political Science, n. 32, p. 455-487.

MANIN, Bernard (1987). "On legitimacy and political deliberation". Political Theory, v. 15, n. 3, p. 338-68.

MANSBRIDGE, Jane (1980). Beyond adversary democracy. Chicago: Chicago University Press.

MANSBRIDGE, Jane et al. (2010). "The place of self-interest and the role of power in deliberative democracy". The Journal of Political Philosophy, v. 18 , n. 1, p. 64-100.

MIGUEL, Luis Felipe (2000). "Sorteios e representação democrática”. Lua Nova, n. 50, p. 69-96.

OFFE, Claus \& PREUSS, Ulrich (1991). "Democratic institutions and moral resources”, em HELD, David (ed.). Political theory today. Stanford: Stanford University Press.

PARKINSON, John (2006). Deliberating in the real world: problems of legitimacy in deliberative democracy. Oxford: Oxford University Press. PETTIT, Philip (1997). Republicanism: a theory of freedom and government. Oxford: Oxford University Press.

(2001). "Deliberative democracy and the discursive dilemma". Philosophical Issues, n. 11, p. 268-99.

(2003). "Deliberative democracy, the discursive dilemma, and republican theory", em FISHKIN, James \& LASLETT, Peter (eds.). Philosophy, politics and society. Vol. 7. Cambridge: Cambridge University Press.

(2004). "Depoliticizing democracy”. Ratio Juris, v. 17, n. 1, p. 52-65. PITKIN, Hannah, \& SHUMER, Sara (1982). “On participation”. Democracy, n. 2, p. 43-54.

PLOTKE, David (1997). "Representation is democracy". Constellations, v. 4, n. 1, p. 19-34.

RICHARDSON, Henry (2002). Democratic autonomy: public reasoning about the ends of policy. Oxford: Oxford University Press.

RIKER, William (1982). Liberalism against populism: a confrontation between the theory of democracy and the theory of social choice. São Francisco: W. H. Freeman. 
ROSENBLUM, Nancy (2008). On the side of angels: an appreciation of parties and partisanship. Princeton: Princeton University Press.

RYFE, David (2005). “Does deliberative democracy work?”. Annual Review of Political Science, n. 8, p. 49-71.

SHAPIRO, Ian (2003). The state of democratic theory. Princeton: Princeton University Press.

SILVA, Filipe Carreira da (2004). Virtude e democracia: um ensaio sobre ideias republicanas. Lisboa: Imprensa de Ciências Sociais.

SINTOMER, Yves (2010). "Random selection, republican self-government, and deliberative democracy”. Constellations, n. 17, p. 472-487.

STEINER, Jürg; BÄCHTIGER, André; SPÖRNDLI, Markus \& STEENBERGEN, Marco (2004). Deliberative politics in action: analyzing parliamentary discourse. Cambridge: Cambridge University Press.

SUNSTEIN, Cass R. (2002). "On a danger of deliberative democracy". Daedalus, v. 131, n. 4, p. 120-124.

URBINATI, Nadia (2000). "Representation as advocacy". Political Theory, v. 28 , n. 6 , p. $758-786$.

(2010). "Unpolitical democracy”. Political Theory, v. 38, n. 1, p. 65-92.

VIEIRA, Mónica Brito \& RUNCIMAN, David (2008). Representation. Cambridge: Polity Press.

WARREN, Mark E. \& PEARSE, Hilary (eds.) (2008). Designing deliberative democracy: the British Columbia Citizens' Assembly. Cambridge: Cambridge University Press.

YACK, Bernard (2006). "Rhetoric and public reasoning: an Aristotelian understanding of public deliberation". Political Theory, v. 34, n. 4, p. 417-438.

YOUNG, Iris Marion (1997). Intersecting voices: dilemmas of gender, political philosophy, and policy. Princeton: Princeton University Press. (2000). Inclusion and democracy. Oxford: Oxford University Press.

\section{Resumo}

Desde meados da década de 1990, o ideal deliberativo tem vindo a assumir um papel central na teoria democrática contemporânea. Mais recentemente, outra tendência tem vindo a registrar-se: a democracia deliberativa está a deixar de ser uma proposta puramente teórica e a tornar-se num modelo regulador de soluções institucionais concretas. É por essa 
razão que os principais problemas com que a democracia deliberativa se confronta hoje em dia são, por um lado, o da sua "institucionalização" e, por outro, o da sua articulação com outros mecanismos democráticos de natureza não deliberativa. Quanto ao primeiro problema, o artigo lança um olhar crítico sobre a forma como a democracia deliberativa vem sendo institucionalizada, discutindo os perigos de despolitização e de dissolução do projeto democrático emancipatório que tal institucionalização potencialmente acarreta. No que se refere à relação entre deliberação e outros mecanismos democráticos como a negociação ou a agregação de preferências individuais, por oposição às quais havia sido tradicionalmente definida, defendemos que a democracia deliberativa depende hoje da renúncia a esse antagonismo de origem, e do seu envolvimento numa relação de complementaridade - não de complementaridade passiva, mas antes transformadora - com esses outros elementos essenciais à vida política democrática.

Palavras-chave: democracia deliberativa; preferências; institucionalização; minipúblicos; representação política.

\section{Abstract}

Since the 1990s the deliberative ideal has come to play a central role in contemporary democratic theory. More recently, however, another trend has emerged: deliberative democracy has ceased to be a purely theoretical approach to become the regulatory ideal of concrete institutional solutions. As a result of this shift, the main problems facing deliberative democracy today are, on the one hand, those of its institutionalisation, and, on the other hand, those of its articulation with other democratic mechanisms of a non-deliberative nature. As to the first of these problems, this article critically addresses the way in which deliberative democracy has been institutionalized, discussing the perils of depoliticization and of dissolution of the emancipatory potential of deliberative democracy that such an institutionalisation might entail. As to the relationship between deliberation and other democratic mechanisms such as negotiation or aggregation of individual preferences, in opposition to which deliberative democracy had originally been defined, we argue that the future of deliberative democracy depends on renouncing that original antagonism. Instead, deliberation should engage in a complementary relationship - albeit not passive, but active - with these other essential constitutive elements of democratic political life.

Key words: deliberative democracy; preferences; institutionalization; mini-publics; political representation.

Recebido em 27 de outubro de 2011.

Aprovado em 31 de março de 2012. 